\title{
Plant-Based Indole Alkaloids: A Comprehensive Overview from a Pharmacological Perspective
}

\author{
Faisal Omar ${ }^{1}$, Abu Montakim Tareq ${ }^{1} \mathbb{D}$, Ali M. Alqahtani ${ }^{2} \mathbb{D}$, Kuldeep Dhama ${ }^{3} \mathbb{D}$, Mohammed Abu Sayeed $^{1, *}$, \\ Talha Bin Emran $4, *$ (D) and Jesus Simal-Gandara $5, *$ (D)
}

1 Department of Pharmacy, International Islamic University Chittagong, Chittagong 4318, Bangladesh; faisal27.omar@gmail.com (F.O.); montakim0.abu@gmail.com (A.M.T.)

2 Department of Pharmacology, College of Pharmacy, King Khalid University, Abha 62529, Saudi Arabia; amsfr@kku.edu.sa

3 Division of Pathology, ICAR-Indian Veterinary Research Institute, Izatnagar, Bareilly 243122, Uttar Pradesh, India; kdhama@rediffmail.com

4 Department of Pharmacy, BGC Trust University Bangladesh, Chittagong 4381, Bangladesh

5 Nutrition and Bromatology Group, Department of Analytical and Food Chemistry, Faculty of Food Science and Technology, University of Vigo-Ourense Campus, E32004 Ourense, Spain

* Correspondence: pmasayeed@yahoo.com (M.A.S.); talhabmb@bgctub.ac.bd (T.B.E.); jsimal@uvigo.es (J.S.-G.); Tel.: +88-0-167-041-9435 (M.A.S.); +88-0-181-994-2214 (T.B.E.); +34-988-387000 (J.S.-G.)

\section{check for}

updates

Citation: Omar, F.; Tareq, A.M.; Alqahtani, A.M.; Dhama, K.; Sayeed, M.A.; Emran, T.B.; Simal-Gandara, J. Plant-Based Indole Alkaloids: A Comprehensive Overview from a Pharmacological Perspective. Molecules 2021, 26, 2297. https:// doi.org/10.3390/molecules26082297

Academic Editors: Enrique Barrajon, Vicente Micol and

María Herranz-López

Received: 14 March 2021

Accepted: 12 April 2021

Published: 15 April 2021

Publisher's Note: MDPI stays neutral with regard to jurisdictional claims in published maps and institutional affiliations.

Copyright: (c) 2021 by the authors. Licensee MDPI, Basel, Switzerland. This article is an open access article distributed under the terms and conditions of the Creative Commons Attribution (CC BY) license (https:// creativecommons.org/licenses/by/ $4.0 /)$.
Abstract: Plant-based indole alkaloids are very rich in pharmacological activities, and the indole nucleus is considered to contribute greatly to these activities. This review's fundamental objective is to summarize the pharmacological potential of indole alkaloids that have been derived from plants and provide a detailed evaluation of their established pharmacological activities, which may contribute to identifying new lead compounds. The study was performed by searching various scientific databases, including Springer, Elsevier, ACS Publications, Taylor and Francis, Thieme, Wiley Online Library, ProQuest, MDPI, and online scientific books. A total of 100 indole compounds were identified and reviewed. The most active compounds possessed a variety of pharmacological activities, including anticancer, antibacterial, antiviral, antimalarial, antifungal, anti-inflammatory, antidepressant, analgesic, hypotensive, anticholinesterase, antiplatelet, antidiarrheal, spasmolytic, antileishmanial, lipid-lowering, antimycobacterial, and antidiabetic activities. Although some compounds have potent activity, some only have mild-to-moderate activity. The pharmacokinetic profiles of some of the identified compounds, such as brucine, mitragynine, 7-hydroxymitragynine, vindoline, and harmane, were also reviewed. Most of these compounds showed promising pharmacological activity. An in-depth pharmacological evaluation of these compounds should be performed to determine whether any of these indoles may serve as new leads.

Keywords: indole; alkaloids; pharmacological activity; pharmacokinetic profile; scientific databases

\section{Introduction}

Nature has always been a blessing for the field of medicine, and peoples throughout history have used natural substances for the treatment of various diseases. The sources of natural substances can be both plants and animals, and an enormous number of pharmacologically active compounds have been derived from natural sources. Many compounds isolated from natural sources have been used as drugs for treatment purposes, either with or without modifications. Through the work of ongoing research, thousands of active compounds have been isolated from natural sources, which can be classified into multiple compound classes. Alkaloids refer to a broad class of compounds, and many of the isolated bioactive compounds have been further classified as indole alkaloids. Many of the therapeutically active indole alkaloids (Figure 1) are isolated from plants, and these compounds have had a noticeable impact on the practice of medicine. Adolf von Baeyer was the first to synthesize indole from oxindole using zinc dust in 1866 [1]. Due to the 
occurrence of adverse effects following treatment with existing drug molecules, the search for new compounds associated with fewer adverse effects has gained immense attention from medicinal chemists and other scientists worldwide. Some of the indole compounds that have since been developed, including vincristine and vinblastine (anticancer agents), reserpine (an antihypertensive agent), physostigmine (a cholinesterase inhibitor), and ajmaline (an anti-arrhythmic agent), are now used as therapeutic drugs.

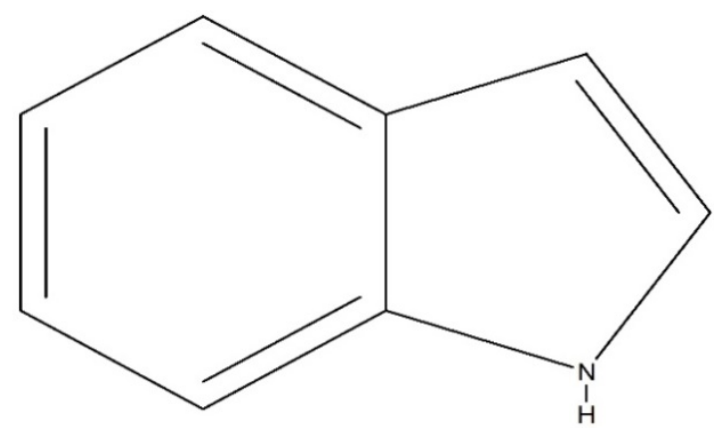

Figure 1. Chemical structure of indole.

This review summarizes current insights regarding the development of plant-based indole alkaloids with biological activities. In this review, 100 indole alkaloids are discussed, including an overview of their pharmacological activities and pharmacokinetic profiles. All information on the compounds was retrieved from scientific databases, such as Springer, Elsevier, ACS Publications, Taylor and Francis, Thieme, Wiley Online Library, ProQuest, MDPI, and online scientific books.

\section{Indole Alkaloids: An Overview}

Indole $\left(\mathrm{C}_{8} \mathrm{H}_{7} \mathrm{~N}\right)$ is a weakly basic molecule consisting of a pyrrole ring fused to a benzene nucleus, and ten $\pi$ electrons move throughout the structure. The basic environment of indole alkaloids is thought to be caused by the delocalization of the lone pair of nitrogen electrons into the free circulation of the $\pi$ electronic system. This results in indole becoming protonated at the C-3 position, which is thermodynamically more stable [2-4].

Indole alkaloids have gained popularity due to their diverse pharmacological activities. Although both plant and marine sources of indole alkaloids are now being extensively studied worldwide, the present review emphasizes only those indole alkaloids that have been derived from plant sources. Indole alkaloids have been identified in several prominent plant families, including Apocynaceae, Rubiaceae, Nyssaceae, and Loganiaceae, among others. Some of the identified indole alkaloid compounds have been highly effective in pre-clinical and clinical studies. Thousands of compounds containing the indole nucleus have been isolated from plant sources. Their pharmacological activities were assessed, with some now being examined in clinical trials and some already approved for therapeutic use in humans. Indole alkaloids are often characterized by their potent biological activities, which are relevant to the field of medicine, including anticancer, antibacterial, antiviral, antimalarial, antifungal, anti-inflammatory, antidepressant, analgesic, hypotensive, anticholinesterase, antiplatelet, antidiarrheal, spasmolytic, antileishmanial, lipid-lowering, antimycobacterial, and antidiabetic activities [2-4].

\section{Pharmacological Activities}

\subsection{Antimicrobial Activity}

Scholarisins I, II, III, and scholarisine F were isolated from the leaves of Alstonia rupestris, and the antifungal activities of these compounds were tested by the disk diffusion method. The zones of inhibition and the minimum inhibitory concentrations (MICs) were determined against five species of fungi, and these compounds displayed inhibitory activities against two species of fungi (Gibberella pulicaris and Cercospora nicotianae), with MIC values of 0.64-0.69 mM, 1.37-1.44 $\mu \mathrm{M}, 1.80-1.91 \mu \mathrm{M}$, and 1.55-1.71 $\mu \mathrm{M}$, respectively [5]. 
Kopsihainins D, E, F, and kopsiflorine were isolated from the twigs of Kopsia hainanensis. The antibacterial activities of these four compounds were examined against Staphylococcus aureus using the disk diffusion method. These compounds exhibited inhibitory activity, forming antibacterial regions with diameters of $11.2,9.1,10.3$, and $9.7 \mathrm{~mm}$, respectively [6].

Erchinines A and B have shown significant antibacterial and antifungal activities against Trichophyton rubrum and Bacillus subtilis. Both compounds were isolated from the roots of Ervatamia chinensis, and they exhibited potent activity, with the MIC values of 0.78 and $0.78 \mu \mathrm{g} / \mathrm{mL}$ against Bacillus subtilis and 12.5 and $6.25 \mu \mathrm{g} / \mathrm{mL}$ against Trichophyton rubrum, respectively [7].

Melokhanines B, D, E, and F exhibited excellent antibacterial activities against Pseudomonas aeruginosa. The MIC values for these compounds were 5, 4, 2, and $2 \mu \mathrm{M}$, respectively. Moreover, melokhanine $\mathrm{B}$ and $\mathrm{E}$ also showed antibacterial activity against Enterococcus faecalis, with a MIC value of $5 \mu \mathrm{M}$ for both compounds (Figure 2) [8].

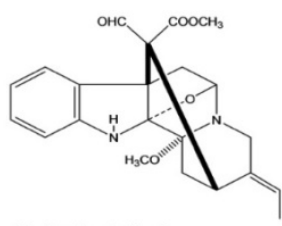

Scholarisin I

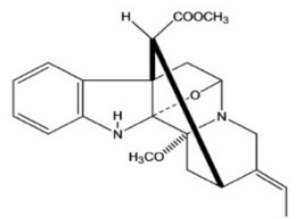

Scholarisine F

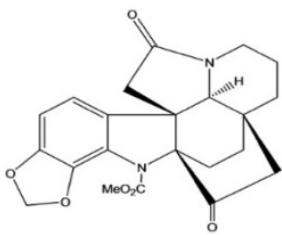

Kopsihainin F

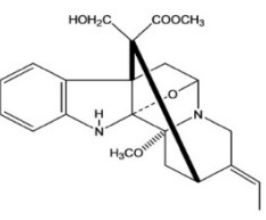

Scholarisin II

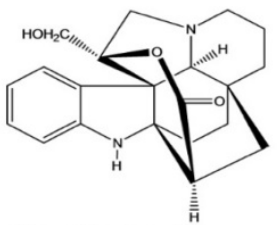

Kopsihainin D

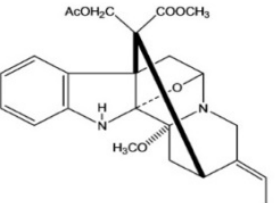

Scholarisin III

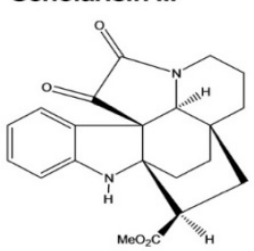

Kopsihainin E
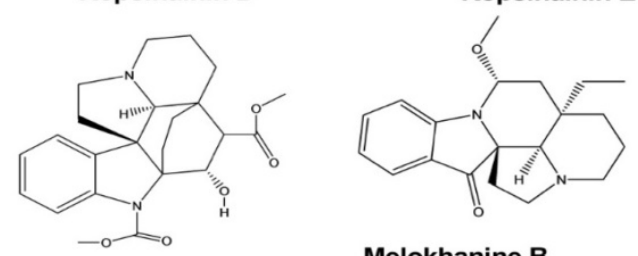

Melokhanine B

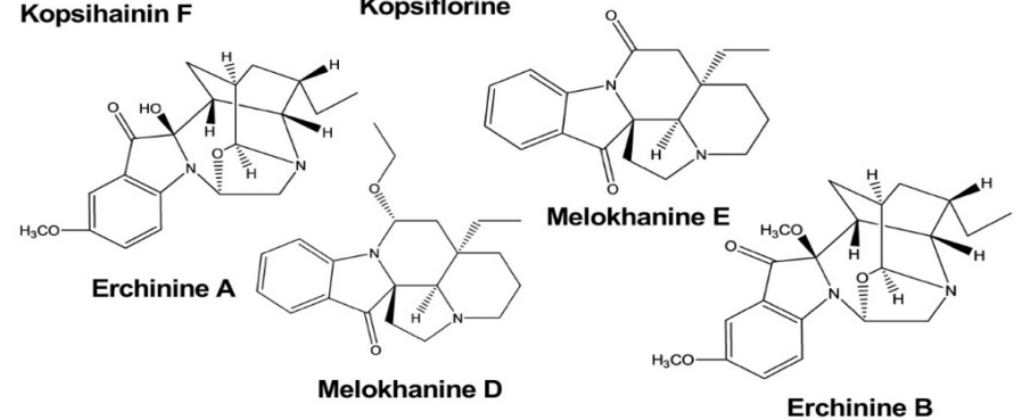

Figure 2. Antimicrobial activity of indole alkaloids.

\subsection{Antiviral Activity}

The compounds 17-nor-excelsinidine and strictamine were extracted from the twigs and leaves of Alstonia scholaris. These compounds were shown to significantly inhibit herpes simplex virus (HSV) and adenovirus (ADV), with half-maximal effective concentrations $\left(\mathrm{EC}_{50}\right)$ of 1.09 and $0.36 \mu \mathrm{g} / \mathrm{mL}$ against HSV and 0.94 and 0.28 against ADV, respectively [9].

Trigonoliimine A was extracted from the leaves of Trigonostemon lii. This compound was evaluated for anti-HIV-1 activity using a microtiter syncytium formation infectivity assay and was found to exhibit a moderate level of inhibitory activity, with an $\mathrm{EC}_{50}$ value of $0.95 \mu \mathrm{g} / \mathrm{mL}$ [10]. 
Naucleaoffines A and B were isolated from the leaves and stems of Nauclea officinalis. Both of these compounds have shown significant effects against HIV-1, with $\mathrm{EC}_{50}$ values of 0.06 and $0.23 \mu \mathrm{M}$, whereas the positive control demonstrated an $\mathrm{EC}_{50}$ value of $0.018 \mu \mathrm{M}$ (Figure 3) [11].

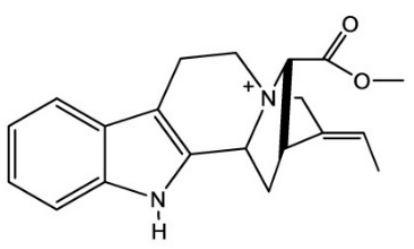

17-nor-excelsinidine<smiles>COc1ccc2c(c1)N=CN1CCc3c([nH]c4ccccc34)C3=NCCC321</smiles>

Trigonoliimine A<smiles>CC=C1CN2CC[C@H]3c4ccccc4NC2(C)[C@]3(C)C[C@H]1C(=O)OC</smiles>

Strictamine

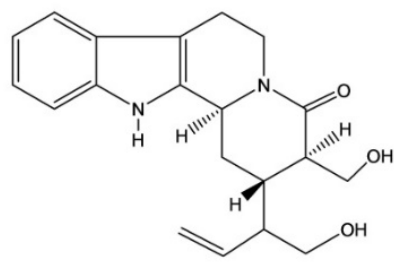

Naucleaoffine A

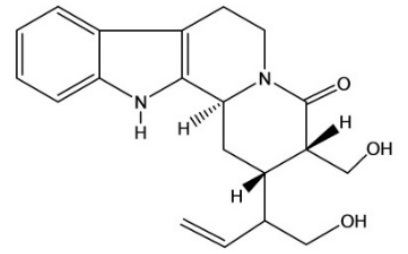

Naucleaoffine B

Figure 3. Antiviral activity of indole alkaloids.

\subsection{Antidepressant Activity}

Mitragynine is an indole alkaloid isolated from Mitragyna speciosa Korth. The antidepressant activity of mitragynine was examined using the forced swim test (FST) and tail suspension test (TST) in a mouse model of depression. Mitragynine significantly decreased the immobility periods of mice in both the FST and TST without noticeable effects on locomotor activity in the open-field test when administered at doses of 10 and $30 \mathrm{mg} / \mathrm{kg}$. The release of corticosterone in mice exposed to the FST and TST was found to be considerably diminished following treatment with mitragynine at doses that provided effective antidepressant effects [12].

Lyaloside and strictosamide exhibited an inhibitory effect against monoamine oxidase (MAO), although this effect was not significant. However, these compounds may represent new leads for the development of analogs with potential antidepressant effects. Lyaloside and stratosamide inhibited MAO-A with half-maximal inhibitory concentrations $\left(\mathrm{IC}_{50}\right)$ values of $50.04 \pm 1.09$ and $132.5 \pm 1.33 \mu \mathrm{g} / \mathrm{mL}$, respectively, and MAO-B inhibition occurred at $\mathrm{IC}_{50}$ values of $306.6 \pm 1.40$ and $162.8 \pm 1.26 \mu \mathrm{g} / \mathrm{mL}$. Lyaloside and strictosamide were isolated from Psychotria suterella and Psychotria laciniata, respectively [13].

Harmane, norharmane, and harmine exhibited antidepressant-like activity when administered to mice subjected to the FST. In a dose-dependent manner, these compounds decreased the immobility duration with a $50 \%$ effective dose $\left(E D_{50}\right)$ of $11.5 \mathrm{mg} / \mathrm{kg}$ by intraperitoneal (i.p.) administration for harmane, $8.5 \mathrm{mg} / \mathrm{kg}$ i.p. for norharmane, and $8 \mathrm{mg} / \mathrm{kg}$ i.p. for harmine. These effects do not appear to be mediated by presynaptic monoaminergic mechanisms but are likely caused by an inverse-agonistic mechanism that involves the benzodiazepine receptors [14].

Psychollatine was isolated from the plant Psychotria umbellate. Psychollatine increased the number of crossings, rearings, and head-dips of treated mice during the hole-board test at the doses of 7.5 and $15 \mathrm{mg} / \mathrm{kg}$. In the light/dark test, psychollatine increased the time spent in the light area and the latency to the first entry into the dark compartment when 
administered at a dose of $7.5 \mathrm{mg} / \mathrm{kg}$. In the FST, psychollatine significantly diminished the duration of immobility in mice at doses of 3 and $7.5 \mathrm{mg} / \mathrm{kg}$ (Figure 4) [15].<smiles>CC[C@H]1CN2CCc3c([nH]c4cccc(OC)c34)[C@@]2(C)C[C@@H]1/C(=C\OC)C(=O)OC</smiles>

Mitragynine<smiles>C=C[C@H]1[C@H](O[C@@H]2OC(CO)[C@@H](O)[C@H](O)[C@H]2O)OC=C2C(=O)N3CCc4c([nH]c5ccccc45)[C@@]3(C)C[C@]21C</smiles>

Strictosamide<smiles>Cc1nccc2c1[nH]c1ccccc12</smiles>

Harmane<smiles>COc1ccc2c(c1)[nH]c1c(C)nccc12</smiles>

Harmine<smiles>C=C[C@H]1[C@@H](Cc2nccc3c2[nH]c2ccccc23)OC=C(C(=O)OC)[C@@H]1OC1O[C@H](CO)[C@@H](O)[C@H](O)[C@H]1O</smiles>

Lyaloside<smiles>[2H][C@@]12C(C3NCCc4c3[nH]c3ccccc43)=CC[C@@H]1C(C(=O)OC)=CO[C@@H]2C[C@H]1O[C@H](CO)[C@@H](O)[C@H](O)[C@H]1O</smiles>

Psychollatine<smiles>c1ccc2c(c1)[nH]c1cnccc12</smiles>

Norharmane

Figure 4. Antidepressant activity of indole alkaloids.

\subsection{Anticancer Activity}

Tabersonine was isolated from the leaves and twigs of Melodinus fusiformis. This compound exhibited significant anticancer activity against five human tumor cell lines, with $\mathrm{IC}_{50}$ values of 4.6, 5.6, 14.8, 9.9, and 12.1 against SW480, SMMC-7721, HL-60, MCF-7, and A-549 cells, respectively [16].

Brucine displayed significant cytotoxic activity against the human hepatoma cell line HepG2, with $\mathrm{IC}_{50}$ values of $0.65,0.32$, and $0.10 \mathrm{mM}$ at a different time interval after treatment. Brucine was isolated from the seeds of Strychnos nux-vomica L. Strychnine and isostrychnine, which were extracted from the same plant, also showed cytotoxic activity [17].

Naucleaorals A and B were isolated from the roots of Nauclea orientalis. Both compounds showed cytotoxic activity against the KB (human epidermoid carcinoma) and HeLa (human cervical carcinoma) cell lines. However, Naucleaoral A showed substantial cytotoxicity, with an $\mathrm{IC}_{50}$ value of $4.0 \mu \mathrm{g} / \mathrm{mL}$ against HeLa cells, whereas Naucleaoral B showed only very moderate cytotoxicity, with $\mathrm{IC}_{50}$ values of 7.8 and $9.5 \mu \mathrm{g} / \mathrm{mL}$ against the two cell lines [18].

Vallesiachotamine and iso-vallesiachotamine were isolated from the fruits of Anthocephalus cadamba (Roxb) Miq. Both compounds showed potent anticancer activity, with $\mathrm{IC}_{50}$ values of 4.24 and $3.79 \mu \mathrm{M}$, respectively, against the human lung cancer cell line H1299 after $72 \mathrm{~h}$ of incubation [19]. 
Ervachinines A, C, and D exhibited significant inhibitory effects against five cancer cell lines, including HL-60 human myeloid leukemia cells, SMMC-7721 hepatocellular carcinoma cells, A-549 lung cancer cells, MCF-7 breast cancer cells, and SW480 colon cancer cells. Except for ervachinine D against MCF-7 cells, all three compounds displayed $\mathrm{IC}_{50}$ values in the range of $0.84-4.63 \mu \mathrm{M}$ against all five cancer cell lines. These compounds were extracted from the Ervatamia chinensis whole plant [20].

Jerantinines A and B were extracted from the plant Tabernaemontana corymbosa. These compounds exhibited inhibitory effects against three cancer cell lines, as determined by the 3-(4,5-dimethylthiazol-2-yl)-2,5-diphenyltetrazolium bromide (MTT) assay. The half-maximal growth inhibitory concentration (GI50) was calculated, which showed that jerantinine A displayed an inhibitory effect against breast, colon, and lung carcinoma cell lines, with the GI50 values less than $4.00 \mu \mathrm{M}$. Jerantinine B showed significant activity against all cell lines except MCF-7 cells, with GI50 values less than $1.00 \mu \mathrm{M}$. Jerantinine A also blocked the ability of cancer cells to form colonies (Figure 5) [21].
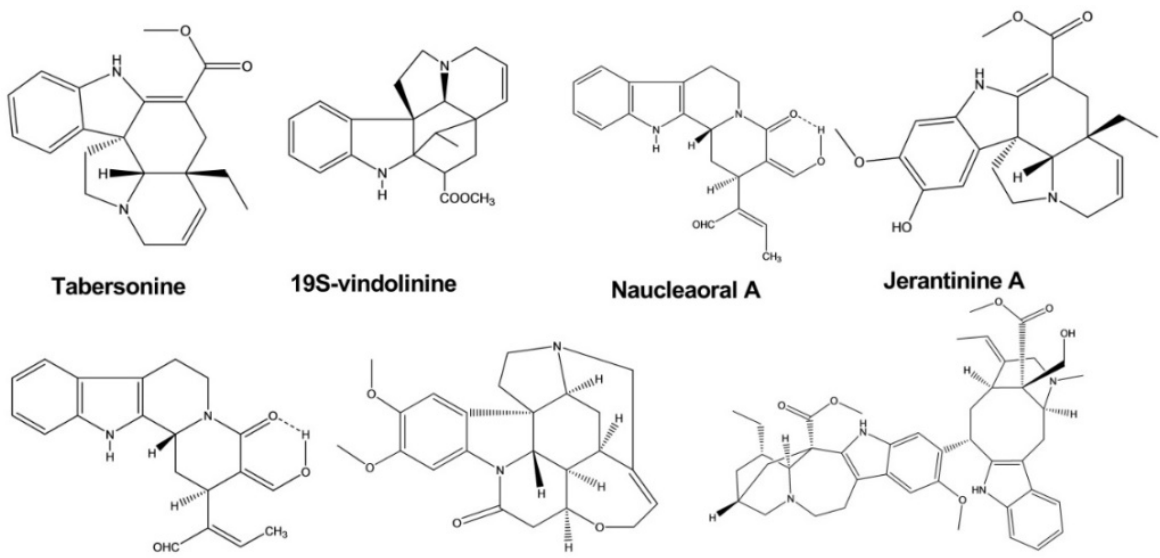

Naucleaoral B

Brucine

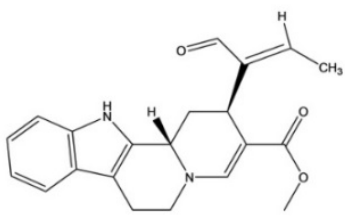

Vallesiachotamine

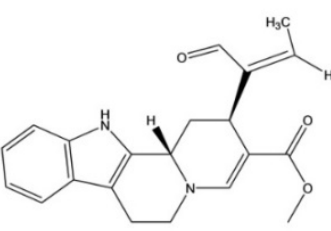

Iso-vallesiachotamine

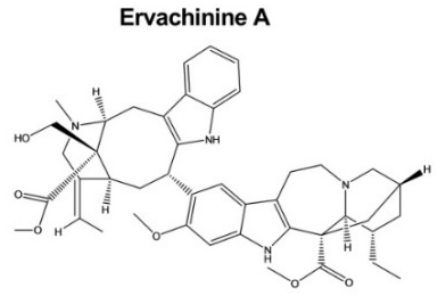

Ervachinine C

Figure 5. Anticancer activity of indole alkaloids.

\subsection{Anti-Inflammatory Activity}

Melaxillines A and B, two alkaloids containing an indole nucleus, were isolated from the roots of Melodinus axillaris. Both compounds showed potent anti-inflammatory activity, as assessed using an in vitro assay to measure the inhibition of $\beta$-glucuronidase secretion induced by platelet-activating factor (PAF) in rat polymorphonuclear leukocytes (PMNs). The $\mathrm{IC}_{50}$ values of these two compounds were 1.51 and $2.62 \mu \mathrm{M}$, respectively [22].

Perakine $\mathrm{N}_{4}$-oxide, raucaffrinoline $\mathrm{N}_{4}$-oxide, and vinorine $\mathrm{N}_{4}$-oxide were isolated from Alstonia yunnanensis. An in vitro anti-inflammatory activity assay revealed selective cyclooxidase 2 (COX-2) inhibition by these three compounds, with inhibitory values of $94.77 \%, 88.09 \%$, and $94.05 \%$, respectively; however, none of these compounds displayed any significant COX-1 inhibition $(<45 \%)$ [23].

Scholarisins I and VI, two monoterpenoid indole alkaloids, were isolated from Alstonia rupestris. Both compounds displayed the selective inhibition of COX-2, with inhibitory values of $96.4 \%$ and $95.5 \%$, respectively, with no significant inhibitory effects against COX-1 [5]. 
Strictosamide showed anti-inflammatory activity against a mouse model of ear edema induced by 12-O-tetradecanoylphorbol-13-acetate (TPA) at doses of 20 and $40 \mathrm{mg} / \mathrm{kg}$. Strictosamide administration significantly diminished the ear swelling rates from $143.9 \pm 8.8$ to $108.4 \pm 11.7$ and $103.5 \pm 16.0$, representing $24.7 \%$ and $28.1 \%$ inhibition against inflammation, respectively. Strictosamide substantially blocked peritoneal capillary permeability induced by acetic acid in mice, with inhibitory rates of $23.3 \%$ and $33.4 \%$ at doses of 20 and $40 \mathrm{mg} / \mathrm{kg}$, respectively. In another test, strictosamide significantly reduced leukocyte counts induced by carboxymethylcellulose sodium (CMC-Na) at doses of 10, 20, and $40 \mathrm{mg} / \mathrm{kg}$, resulting in reductions of $46.0 \%, 49.1 \%$, and $58.7 \%$, respectively (Figure 6) [24].<smiles></smiles>

Melaxilline A

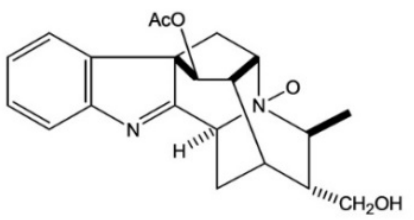

Raucaffrinoline $\mathrm{N}_{\mathbf{4}}$-oxide

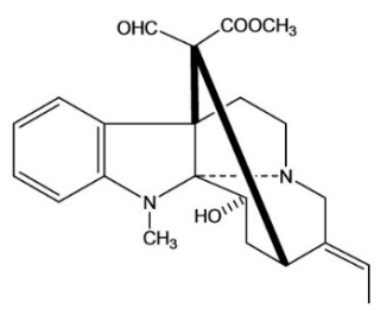

Scholarisin VI<smiles>C=C[C@@]12C[C@@H](O)C(=O)N3CC[C@]4(c5ccccc5NC(=O)[C@]41OC)[C@@H]32</smiles>

Melaxilline B

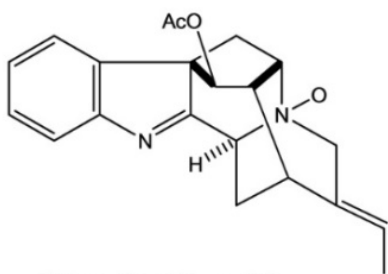

Vinorine $\mathrm{N}_{4}$-oxide

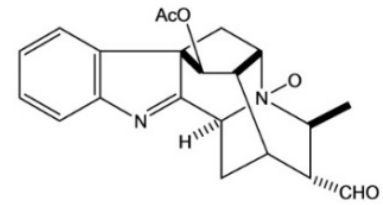

Perakine $\mathrm{N}_{4}$-oxide

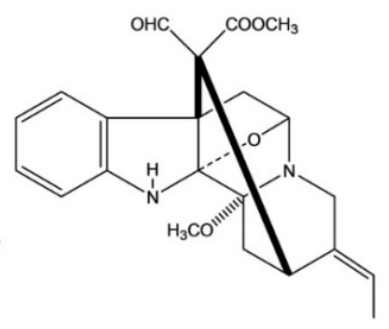

Scholarisin I

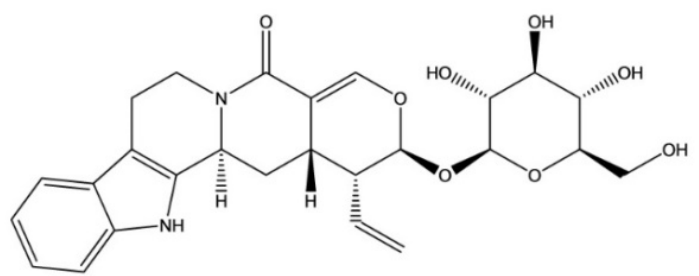

Strictosamide

Figure 6. Anti-inflammatory activity of indole alkaloids.

\subsection{Analgesic Activity}

Brucine and brucine N-oxide were extracted from the seeds of Strychnos nux-vomica. Three different tests, including the hot plate test, writhing test, and formalin test, were conducted to determine whether these compounds exerted analgesic effects. In the formalin test, brucine showed potent inhibitory effects against both the early- and late-phase pain stimuli at doses ranging from 7.5 to $30 \mathrm{mg} / \mathrm{kg}$. However, brucine N-oxide exhibited a significant inhibitory effect only against the late phase. In the writhing test, brucine (15 and $30 \mathrm{mg} / \mathrm{kg}$ ) and brucine N-oxide (50 and $200 \mathrm{mg} / \mathrm{kg}$ ) showed significant inhibition of the writhing response to the i.p. administration of acetic acid in mice. In the hot plate test, the $\mathrm{ED}_{50}$ value of brucine N-oxide was five and six times greater than that of brucine 30 and $60 \mathrm{~min}$ after drug administration, respectively, which indicated that brucine prolonged the pain threshold of mice in a dose-dependent manner [25].

Mitragynine and 7-hydroxymitragynine were isolated from the plant Mitragyna speciosa $[26,27]$. The antinociceptive effects of mitragynine were examined using the hot plate test, which revealed a dose-dependent response at doses ranging from 3-35 mg/ kg. The latency period increased after the administration of the $15 \mathrm{mg} / \mathrm{kg}$ dose. The most significant antinociceptive effect was observed at the $35 \mathrm{mg} / \mathrm{kg}$ mitragynine dose, which corresponded 
with the longest latency time [26]. Similarly, 7-hydroxymitragynine demonstrated antinociceptive activity in a dose-dependent manner $(2.5-10 \mathrm{mg} / \mathrm{kg})$ in the tail-flick and hotplate tests. The maximum possible effect (MPE) value of 7-hydroxymitragynine $(5 \mathrm{mg} / \mathrm{kg}$, subcutaneous (s.c.)) reached 100\% between 15 and $30 \mathrm{~min}$ after administration in the tail-flick test. In the hotplate test, the MPE value of 7-hydroxymitragynine (10 mg/ $\mathrm{kg}$, s.c.) reached $94 \%$ at 15 min after administration [27].

Strictosamide exhibited analgesic activity in the writhing test, with no such effect observed in the hot plate test. The i.p. injection of strictosamide reduced acetic acid-induced writhing in mice in a dose-dependent manner. Strictosamide remarkably lengthened the pain latency of mice at doses of 20 and $40 \mathrm{mg} / \mathrm{kg}$, resulting in latency periods $336.5 \mathrm{~s}$ and $345.8 \mathrm{~s}$, respectively. When the writhing activity was counted, a significant reduction in writhing activity was observed for the $40 \mathrm{mg} / \mathrm{kg}$ dose of strictosamide, which reduced the count to 9.7 compared with the positive drug. The inhibition observed at doses of 20 and $40 \mathrm{mg} / \mathrm{kg}$ were $37.0 \%$ and $49.7 \%$, respectively. This compound was isolated from the Nauclea officinalis [24].

Umbellatine was isolated from the leaves of Psychotria umbellate. Analgesic activity was investigated by conducting the tail-flick test, hot plate test, formalin test, and capsaicininduced pain test. In the four test models, umbellatine exhibited good activity against tail-flick test and hot plate test and significant activity against formalin test and capsaicininduced pain test at the doses of 100-300 mg/kg (Figure 7) [28].

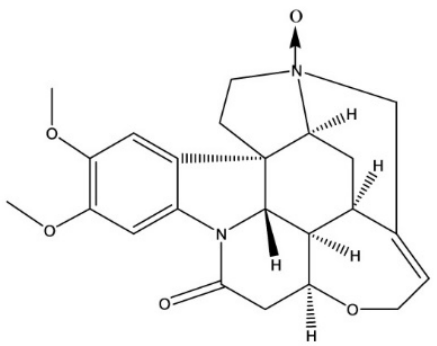

Brucine N-oxide

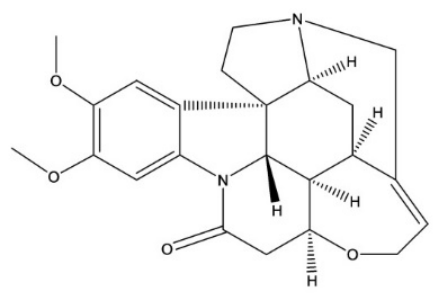

Brucine

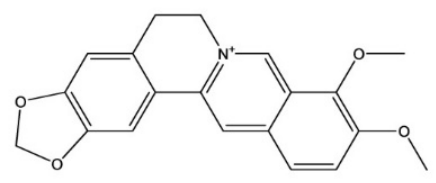

Umbellatine<smiles>[2H][C@]12C[C@H](/C(=C\OC)C(=O)OC)[C@@H](CC)CN1CC[C@]1(O)C2=Nc2cccc(OC)c21</smiles>

7-Hydroxymitragynine<smiles>[2H][C@]12C[C@H](/C(=C\OC)C(=O)OC)[C@@H](CC)CN1CCc1c2[nH]c2cccc(OC)c12</smiles>

Mitragynine

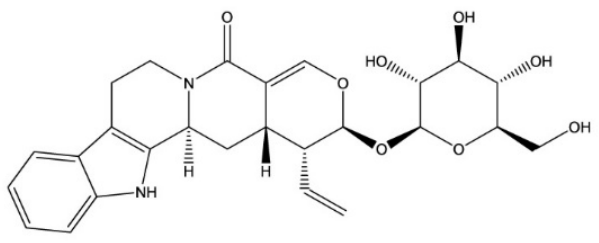

Strictosamide

Figure 7. Analgesic activity of indole alkaloids.

\subsection{Antidiabetic Activity}

Vindoline, vindolidine, vindolicine, and vindolinine represent four new indole-type alkaloids that were extracted from the leaves of Catharanthus roseus (L.) G. Don. All four alkaloids induced enhanced glucose uptake activity in $\beta$-TC6 and $\mathrm{C}_{2} \mathrm{C}_{2}$ cells in a dosedependent manner, and vindolicine triggered an extreme increase in glucose uptake activity. In another test, all of these compounds exhibited protein tyrosine phosphatase $1 \mathrm{~B}(\mathrm{PTP}-1 \mathrm{~B})$ 
inhibition activity, although only vindolicine showed significant inhibitory activity. The $\mathrm{IC}_{50}$ values of vindoline, vindolidine, vindolicine, and vindolinine against PTP-1B were $36.5,18.2,11.6$, and $14.1 \mu \mathrm{M}$, respectively [29].

Vindogentianine was isolated from Catharanthus roseus leaf extracts and resulted in significant hypoglycemic activity in $\beta$-TC6 pancreatic and $\mathrm{C}_{2} \mathrm{Cl}_{2}$ muscle cells at treatment concentrations of $25.0,50.0$, and $100.0 \mu \mathrm{g} / \mathrm{mL}$ by inducing increased glucose uptake activity. The compound also exhibited a significant antihyperglycemic effect in the PTP-1B inhibition test, with an $\mathrm{IC}_{50}$ value of $15.28 \pm 2.59 \mu \mathrm{g} / \mathrm{mL}$ [30].

Akuammicine was isolated from the plant Picralima nitida and significantly enhanced glucose uptake activity in fully differentiated 3T3-L1 adipocytes after $24 \mathrm{~h}$ incubation (Figure 8) [31].

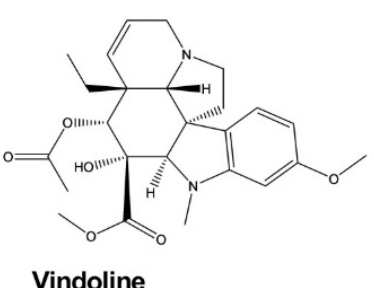

Vindoline

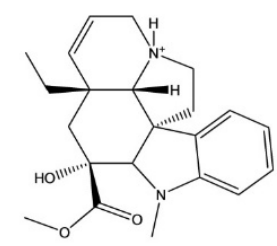

Vindolidine

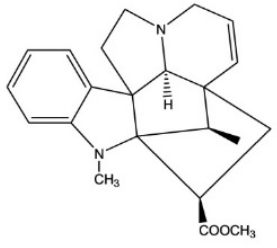

Vindolinine

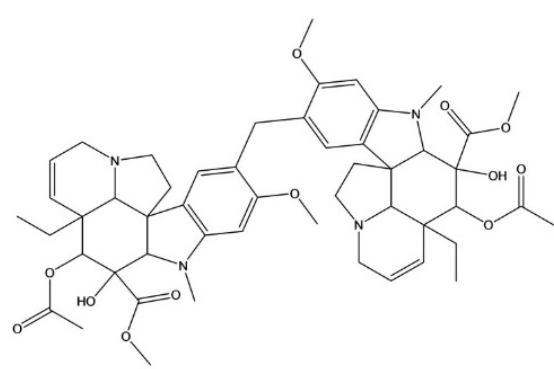

Vindolicine

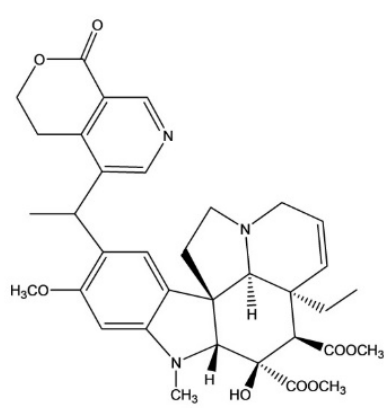

Vindogentianine

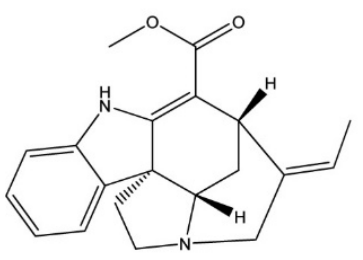

Akuammicine

Figure 8. Antidiabetic activity of indole alkaloids.

\subsection{Antimalarial Activity}

Ellipticine and olivacine, two indole alkaloids, exhibited potential in vitro antimalarial activity against Plasmodium falciparum and in vivo activity in Plasmodium berghei-infected mice. These two compounds were isolated from Aspidosperma vargasii and Aspidosperma olivaceum. Olivacine significantly inhibited $P$. falciparum growth, with an $\mathrm{IC}_{50}$ value of $1.2 \mu \mathrm{M}$ against the K1 P. falciparum strain. Ellipticine displayed significant antimalarial effects, with $\mathrm{IC}_{50}$ values of 0.81 and $0.35 \mu \mathrm{M}$ against the P. falciparum strains K1 and 3D7, respectively. Both compounds displayed high selectivity indices against $P$. falciparum $3 \mathrm{D} 7\left(>1.2 \times 10^{3}\right.$ and $>3.4 \times 10^{2}$, respectively). The in vivo antimalarial activity of these compounds was evaluated in $P$. berghei-infected mice in a four-day suppressive test. Ellipticine showed a significant effect at an oral dose of $50 \mathrm{mg} / \mathrm{kg} /$ day $(100 \%$ inhibition versus controls on days five and seven). The mean survival time (MST) of the animals was greater than 40 days at the same oral dose. Olivacine showed higher activity at the dose equal to $50 \mathrm{mg} / \mathrm{kg} / \mathrm{day}$ in this test. The range of inhibition was $90 \%-97 \%$ at day five and day seven after the oral and subcutaneous administration of the drug, with an MST of 23-27 days [32]. 
Flinderoles A, B, and C showed selective antimalarial activity against the Dd2 strain of $P$. falciparum. These compounds exhibited parasite growth inhibition with $\mathrm{IC}_{50}$ values of 1.42 , 0.15 , and $0.34 \mu \mathrm{M}$, respectively. These compounds were isolated from Flindersia acuminate and F. amboinensis [33].

Apisdospermine, aspidospermine, demethoxy-aspidospermine, vallesine, and palosine were tested for their antimalarial activities against a chloroquine-resistant strain of $P$. falciparum. These compounds displayed better activity after incubation for $72 \mathrm{~h}$ with $\mathrm{IC}_{50}$ values of 3.8, 4.1, 5.6, 6.2, and $12.7 \mu \mathrm{M}$, respectively (Figure 9) [34].<smiles>CNCCc1c2n(c3ccccc13)[C@@H](C=C(C)C)C[C@]2(C)/C=C/C1Nc2ccccc2C1CCNC</smiles>

Flinderole A<smiles>Cc1c2cnccc2c(C)c2c1[nH]c1ccccc12</smiles>

Ellipticine

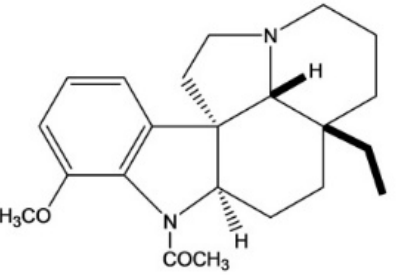

Aspidospermine

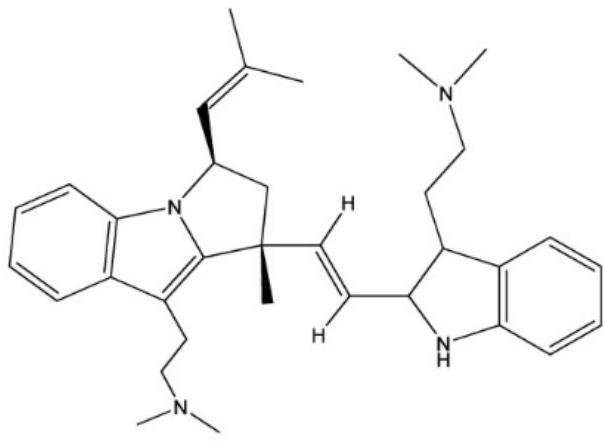

Flinderole B<smiles>Cc1[nH]ccc2c(C)c3nc4ccccc4c3cc12</smiles>

Olivacine<smiles>CC(C)=CC1c2ccccc2NC1/C=C/[C@@]1(C)C[C@H](CCN(C)C)c2c(CCN(C)C)c3ccccc3n21</smiles>

Flinderole C

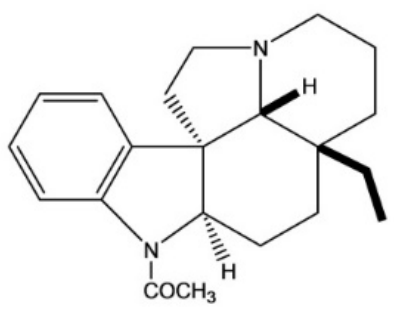

Demethoxy-aspidospermine

Figure 9. Antimalarial activity of indole alkaloids.

Geissolosimine, geissospermine, geissoschizoline, and geissoschizone were evaluated for in vitro antimalarial activity against the chloroquine-sensitive strain of $P$. falciparum (D10), revealing $\mathrm{IC}_{50}$ values of $0.55,3.17,4.16$, and $3.19 \mu \mathrm{g} / \mathrm{mL}$, respectively. Among these compounds, geissolosimine exhibited the greatest antiplasmodial activity, suggesting that it may represent a promising lead for antimalarial drug discovery. All of these compounds were isolated from the stem bark of Geissospermum vellosii (Figure 10) [35]. 


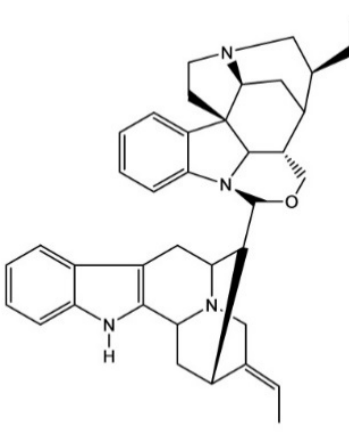

Geissolosimine<smiles></smiles>

Geissoschizoline

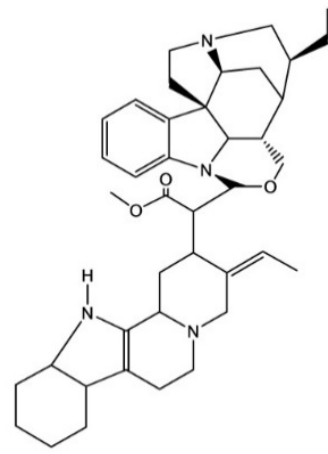

Geissospermine<smiles>CC[C@]12CCCN3CC[C@]4(c5cccc(OC)c5N(C=O)[C@H]4CC[C@@H]31)[C@H]2C</smiles>

Vallesine

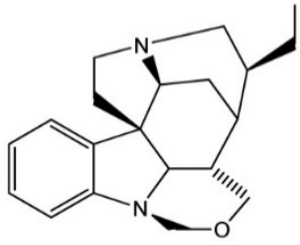

Geissoschizone<smiles>CC[C@H]1[C@@]2(CC)CCCN3CC[C@]14c1cccc(OC)c1N(C(C)=O)[C@H]4[C@@H]32</smiles>

Palosine

Figure 10. Antimalarial activity of indole alkaloids.

\subsection{Hypotensive Activity}

Naucline, angustine, angustidine, nauclefine, and naucletine were isolated from the bark of the Nauclea officinalis. These compounds displayed hypotensive effects against phenylephrine (PE)-induced contractions of rat aortic rings associated with intact endothelium. Naucline showed moderate vasorelaxant activity, resulting in $90 \%$ relaxation at $1 \times 10^{-5} \mathrm{M}$.The remaining compounds showed significant vasorelaxant activity, resulting in greater than $90 \%$ relaxation at $1 \times 10^{-5} \mathrm{M}$ in an isolated rat aorta [36].

Alstilobanines $\mathrm{A}, \mathrm{B}$, and $\mathrm{C}$ and undulifoline displayed slow relaxation activity against PE-induced contractions in thoracic rat aortic rings with intact endothelium. The percentages of relaxation induced by these compounds were $44.3 \%, 21.2 \%, 28 \%$, and $33.3 \%$, respectively, with alstilobanine A showing more potent relaxation activity than the other compounds. The first three compounds were isolated from Alstonia angustiloba, whereas undulifoline was extracted from Alstonia undulifolia [37].

Taberniacins A and B, two new indole alkaloids, were isolated from Tabernaemontana divaricata and displayed hypotensive activity by inducing vasorelaxation to counteract the PE-induced contraction in an isolated rat aorta. Both alkaloids exhibited moderate levels of vasorelaxant activity in an isolated rat aorta. The $\mathrm{IC}_{50}$ values of taberniacins A and B were $2.86 \mu \mathrm{M}$ and $580 \mathrm{nM}$, respectively, and vasorelaxation activity increased in a concentration-dependent manner [38].

Villocarine A demonstrated vasorelaxation activity in a rat aortic ring, with concentrationdependent inhibitory effects against vasocontraction in aorta depolarized by a high potassium concentration and against PE-mediated contraction in the presence of nicardipine. Villocarine A exhibited excellent activity during the initial stage, within 10-30 min after injection, with potent vasorelaxant effects observed at $30 \mu \mathrm{M}$ against PE-mediated contraction in a rat aorta. Villocarine A exhibited a moderate level of inhibition at $30 \mu \mathrm{M}$ against $\mathrm{PE}$ and $1 \mu \mathrm{M}$-induced contraction of the aortic rings in the presence of nicardipine $(1 \mu \mathrm{M})$ in a $\mathrm{Ca}^{2+}$-free medium. Villocarine showed slightly less vascular relaxation activity in aortic tissues with no endothelium. Villocarine A was isolated from Uncaria villosa (Figure 11) [39]. 


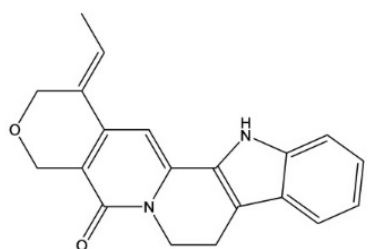

Naucline<smiles>C=Cc1cncc2c(=O)n3c(cc12)-c1[nH]c2ccccc2c1CC3</smiles>

Angustine<smiles>CC1c2c([nH]c3ccccc23)C(CO)(CO)[C@@]2(O)CC[C@H](O)[C@]12O</smiles>

Alstilobanine A<smiles>NC(=O)c1cncc(C2=NCCc3c2[nH]c2ccccc32)c1</smiles>

Taberniacin A

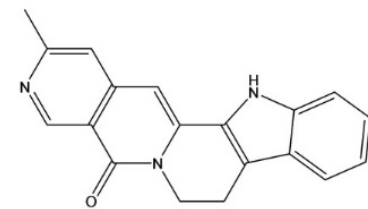

Angustidine

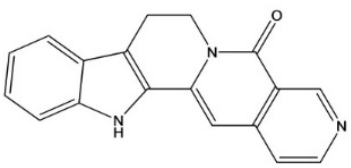

Nauclefine

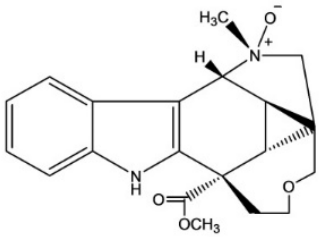

Alstilobanine B

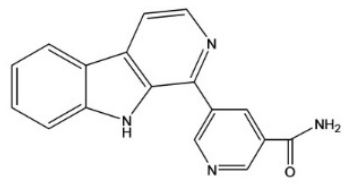

Taberniacin B<smiles>CC(=O)c1cncc2c(=O)n3c(cc12)-c1[nH]c2ccccc2c1CC3</smiles>

Naucletine<smiles></smiles>

Undulifoline

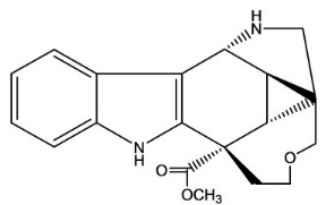

Alstilobanine C

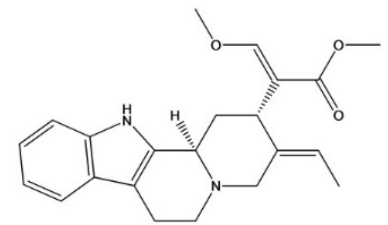

Villocarine A

Figure 11. Hypotensive activity of indole alkaloids.

\subsection{Anticholinesterase Activity}

Macusine B, vinorine, isoreserpiline, and rescinnamine are four indole alkaloids isolated from the bark of Rauvolfia reflexa. These compounds showed inhibitory activities against the cholinesterase enzyme, with the $\mathrm{IC}_{50}$ values of $48.39,35.06,24.89$, and $11.01 \mu \mathrm{M}$, respectively. Rescinnamine displayed the most significant anticholinesterase activity among these four compounds [40].

Voacangine hydroxyindolenine and rupicoline were identified in the chloroform extract of Tabernaemontana australis stalks. These compounds were investigated for their anticholinesterase activity and displayed activities at concentrations similar to those of the standard compounds physostigmine and galanthamine [41].

Coronaridine and voacangine were isolated from the stems of Ervatamia hainanensis. These compounds displayed significant inhibitory activities against the cholinesterase enzyme, with $\mathrm{IC}_{50}$ values of 8.6 and $4.4 \mu \mathrm{M}$, respectively, in in vitro experiments [42].

Angustidine, nauclefine, and angustine, three indole alkaloids, were extracted from the plant Nauclea officinalis. Their cholinesterase inhibitory activities were evaluated, and all three compounds demonstrated anticholinesterase activity, with $\mathrm{IC}_{50}$ values of 1.03, 7.70, and $4.98 \mu \mathrm{M}$, respectively, against the butyrylcholinesterase enzyme (Figure 12) [43]. 

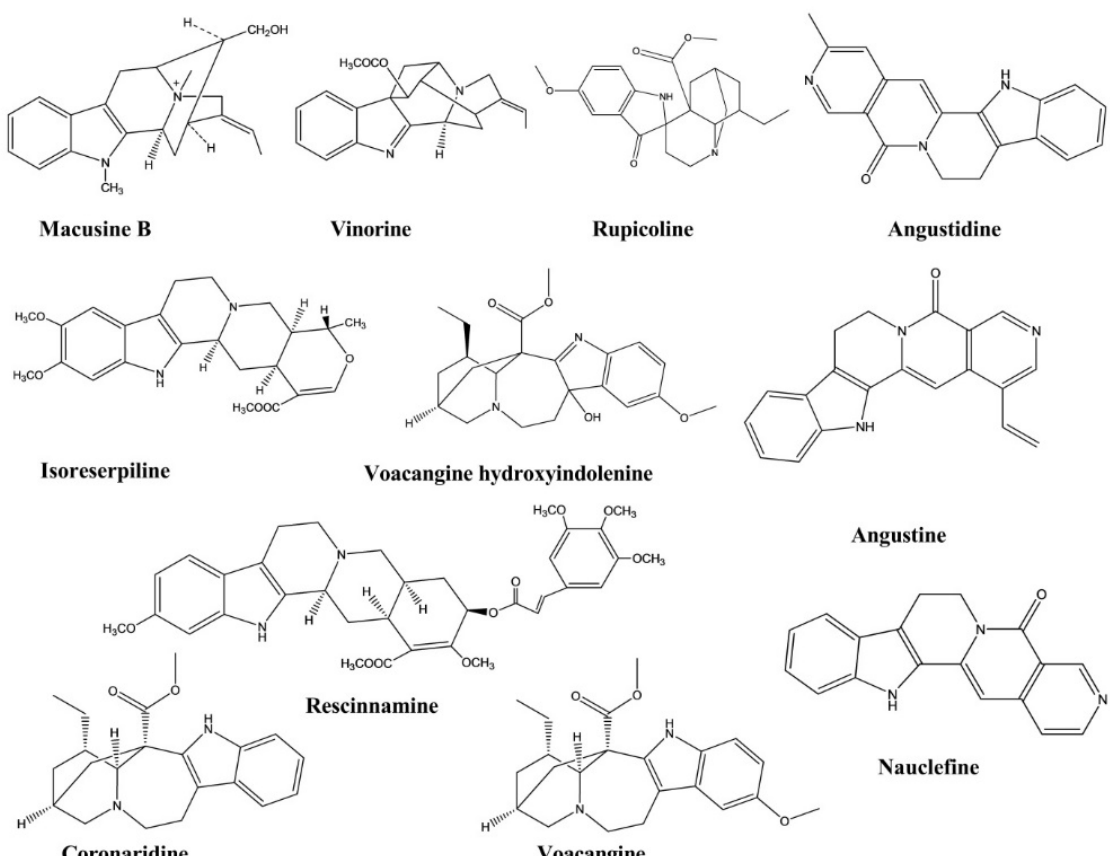

Voacangine hydroxyindolenine

Angustine
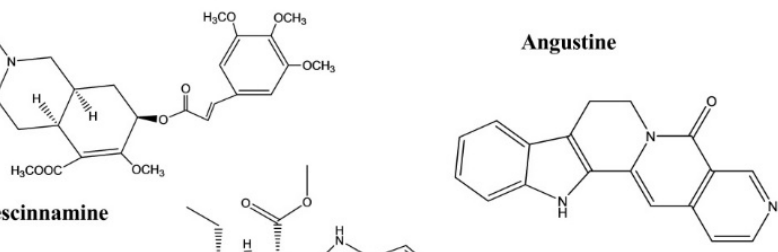

Coronaridine

Voacangine

Nauclefine

Figure 12. Anticholinesterase activity of Indole alkaloids.

\subsection{Antiplatelet Activity}

Harmane, harmine, and harmol were isolated from the plant Perganum harmala L. The antiplatelet activities of these three compounds were examined using the selective inhibition of collagen-mediated platelet activation. The $\mathrm{IC}_{50}$ values of these three compounds were $113.7 \pm 8.4,132.9 \pm 16.6$, and $200 \pm 4.6 \mu \mathrm{M}$, respectively. The underlying mechanism of this effect was also proposed in that study. These compounds had no inhibitory effects on arachidonic acid- or thrombin-induced platelet aggregation at concentrations of $200 \mu \mathrm{M}$ (Figure 13) [44].<smiles>Cc1[nH]ccc2c1[nH]c1cc(=O)ccc12</smiles>

Harmol

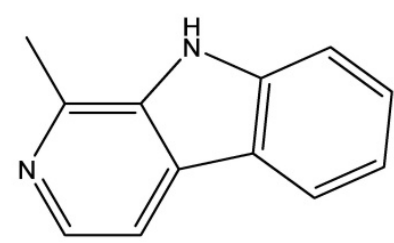

Harmane<smiles>COc1ccc2c(c1)[nH]c1c(C)nccc12</smiles>

Harmine

Figure 13. Antiplatelet activity of indole alkaloids.

\subsection{Antidiarrheal Activity}

Kurryam and koenimbine were isolated from the seeds of Murraya koenigii Spreng. These compounds showed significant antidiarrheal activity in a castor oil-induced diarrhea rat model. The results showed that the mean defecation of rats treated with koenimbine at doses of 10,30 , and $50 \mathrm{mg} / \mathrm{kg}$ were $2.51 \pm 0.58,1.94 \pm 0.81$, and $1.29 \pm 0.21$, respectively, whereas rats treated with the same dose of kurryam had mean defecation of $2.35 \pm 0.35$, $1.88 \pm 0.28$, and $1.21 \pm 0.25$, respectively [45].

Bisnordihydrotoxiferine was extracted from the root bark of Strychnos trinervis (Vell.) Mart. The antidiarrheal effect was evaluated in castor oil-, magnesium sulfate-, and arachidonic acid-induced diarrhea models, and activity was calculated as the percent inhibition. This compound inhibited castor oil-induced diarrhea with an inhibition percentage ranging from $70.0 \%$ to $100.0 \%$ at various doses. Bisnordihydrotoxiferine exhibited $92.5 \%$ inhibition 
at a dose of $25 \mathrm{mg} / \mathrm{kg}$ against magnesium-induced diarrhea and $94.6 \%$ inhibition at the $12.5 \mathrm{mg} / \mathrm{kg}$ dose against arachidonic acid-induced diarrhea (Figure 14) [46].<smiles>COc1cc2[nH]c3c4c(c(C)c(O)c3c2cc1OC)OC(C)(C)C=C4</smiles>

Kurryam<smiles>COc1ccc2[nH]c3c4c(cc(C)c3c2c1)OC(C)(C)C=C4</smiles>

Koenimbine

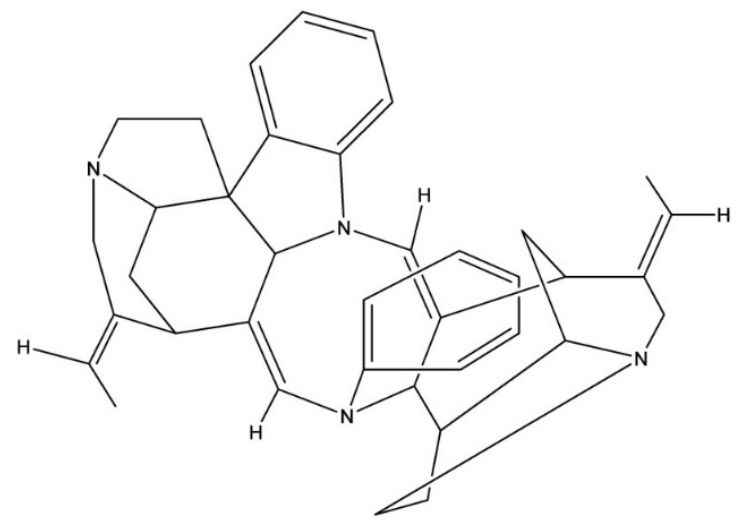

Bisnordihydrotoxiferine

Figure 14. Antidiarrheal activity of indole alkaloids.

\subsection{Spasmolytic Activity}

Trinervine is a tertiary indole alkaloid extracted from the root bark of Strychnos trinervis. The spasmolytic activity was evaluated for this compound using four different methods, including arachidonic acid (AA)- and 5-hydroxytryptamine (5-HT)-induced contractions of the rat fundic strip and the histamine- and carbachol-mediated contractions of the guinea-pig ileum. The values (mean \pm standard error) of the antagonistic potency of trinervine against these four models were $3.96 \pm 0.16$ (AA), $3.54 \pm 0.15$ (5-HT), $4.25 \pm 0.16$ (Histamine), $4.04 \pm 0.12$ (Carbachol). Trinervine yielded a non-competitive, antagonistic, spasmolytic activity on isolated gastrointestinal smooth muscles [47].

Bisnordihydrotoxiferine was extracted from the root of Strychnos diuaricuns. Acetylcholineand oxytocin-induced contractions of the rat uterus and acetylcholine- and histamineinduced contractions of the guinea-pig ileum were used to evaluate the contraction inhibition mediated by bisnordihydrotoxiferine. The percentages of inhibition against acetylcholine- and oxytocin-induced contractions in the rat uterus ranged from $21.1 \%$ to $77.4 \%$ and from $36.6 \%$ to $85.0 \%$, respectively, at three different doses. The percentages of inhibition against contractions caused by acetylcholine and histamine in the guinea-pig ileum ranged from $25.0 \%$ to $57.2 \%$ and $51.5 \%$ to $91.1 \%$, respectively, at three different doses (Figure 15) [48].

Normacusine B is a tertiary indole alkaloid that was isolated from the root bark of Strychnos atlantica. Normacusine B reduced PE- and serotonin-induced contractions in rat aortic rings, with a molar antagonist potency ( $p \mathrm{~A} 2)$ value of $7.05 \pm 0.11$, and noncompetitively inhibits 5-HT-induced contractions with a $p$ A2 value of $7.02 \pm 0.08$ [49].

Harmine, harman, and harmaline were isolated from the seeds of Peganum harmala L. The relaxation potency of these compounds against histamine, carbachol, and $\mathrm{KCl}$-induced contractions revealed EC50 values for harmane, harmine, and harmaline of $28 \pm 3,16 \pm$ 4 , and $20 \pm 3 \mu \mathrm{M}$ against carbachol; $21 \pm 2,10 \pm 2$, and $143 \pm 20 \mu \mathrm{M}$ against histamine, 
$51 \pm 5,37 \pm 3$, and $131 \pm 30 \mu \mathrm{M}$ against $\mathrm{KCl}$, respectively. Harmine displayed the most potency among the three indole alkaloids (Figure 15) [50].

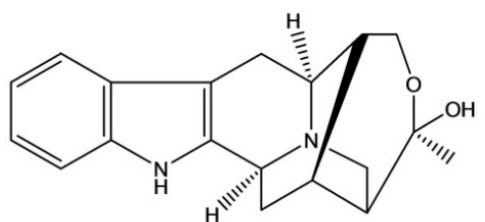

Trinervine<smiles>C/C=C1\CN2C3CC1C(CO)C2Cc1c3[nH]c2ccccc12</smiles>

Normacusine B

\section{Normacusine B}<smiles>COc1ccc2c3c([nH]c2c1)C(C)=NCC3</smiles>

Harmaline

armaline

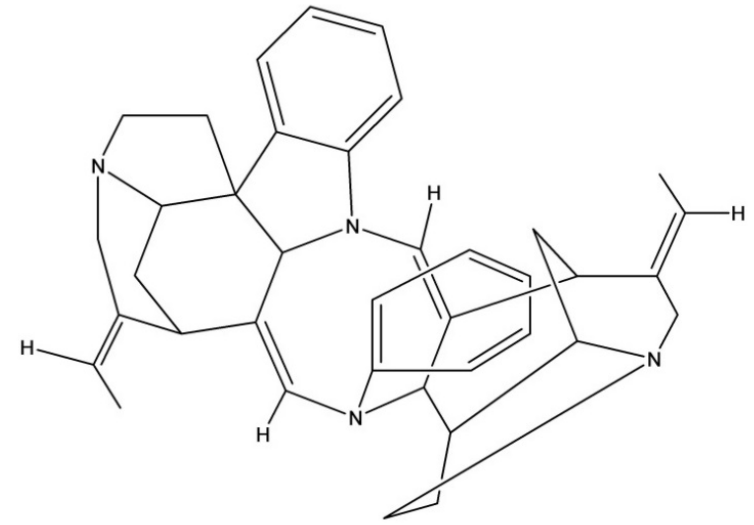

Bisnordihydrotoxiferine

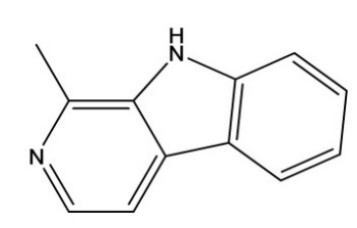

Harmane<smiles>COc1ccc2c(c1)[nH]c1c(C)nccc12</smiles>

Harmine

Figure 15. Spasmolytic activity of indole alkaloids.

\subsection{Antileishmanial Activity}

Ramiflorines A and B were isolated from Aspidosperma ramiflorum. These two indole alkaloids exhibited significant effects against Leishmania amazonensis, a parasite that causes a disease known as leishmaniasis. Ramiflorines A and B displayed inhibitory activity against the parasite, with $\mathrm{LD}_{50}$ values of $16.37 \pm 1.6$ and $4.97 \pm 0.9 \mathrm{mg} / \mathrm{mL}$, respectively, which was 3-10-fold higher than the impacts of the whole-plant alkaloidal extract. Their modes of action were not determined but might be similar to the effects exerted by other corynanthe dimeric indole alkaloids (Figure 16) [51].<smiles>[2H][C@]12C[C@H](C[C@H]3NCCc4c3[nH]c3ccccc43)/C(=C\C)CN1CCc1c2[nH]c2ccc(OC)cc12</smiles>

Ramiflorine A

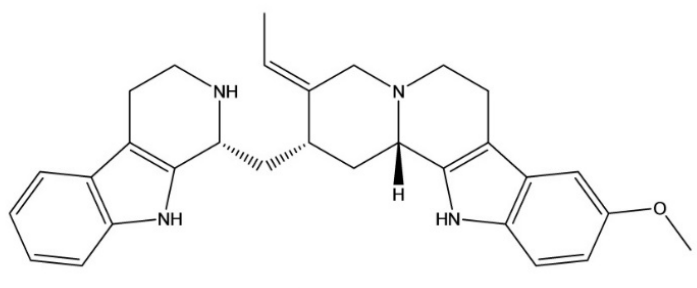

Ramiflorine B

Figure 16. Antileishmanial activity of indole alkaloids. 


\subsection{Lipid-Lowering Activity}

Ellipticine and 9-methoxyellipticine were isolated from Ochrosia borbonica. A triglyceride assay in the 3T3-L1 adipocyte model was used to evaluate the lipid-lowering activity of these two compounds. The results indicated that both compounds significantly reduced the formation of lipid droplet by $80 \%$ at $10 \mu \mathrm{mol} \times \mathrm{L}^{-1}$ and exerted a dose-dependent reduction in lipid formation at a concentration range of $0.01-10 \mu \mathrm{mol} \times \mathrm{L}^{-1}$. The $\mathrm{EC}_{50}$ values of ellipticine and 9-methoxyellipticine were 0.41 and $0.92 \mu \mathrm{mol} \times \mathrm{L}^{-1}$, respectively. This activity might be due to the retardation of adipogenesis and lipogenesis through intercalation into supercoiled DNA [52].

Vincamine was isolated from the plant Vinca minor [53]. At doses of 20 and $30 \mathrm{mg} / \mathrm{kg}$, vincamine exhibited significant reductions in the levels of serum triglycerides (TG), total cholesterol (TC), low-density lipoprotein cholesterol (LDL-C), and very-low-density lipoprotein cholesterol (VLDL-C), and a comparative increase in high-density lipoprotein cholesterol (HDL-C), resulting in the overall improvement of the lipid profile of rats (Figure 17) [54].

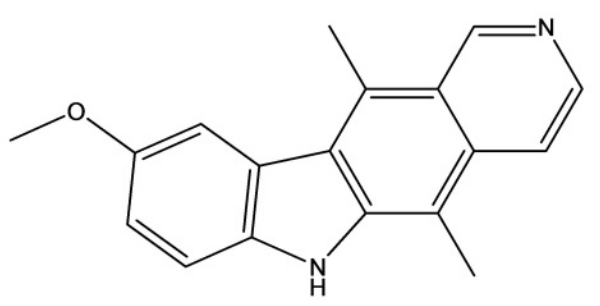

9-methoxyellipticine

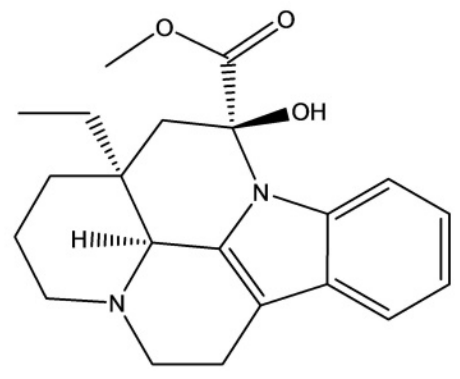

Vincamine<smiles>Cc1c2cnccc2c(C)c2c1[nH]c1ccccc12</smiles>

Ellipticine

Figure 17. Lipid-lowering activity of indole alkaloids.

\subsection{Antimycobacterial Activity}

Coronaridine is an iboga-type indole alkaloid isolated from the root of Tabernaemontana ternifolia that displayed weak inhibitory activity against Mycobacterium tuberculosis. Coronaridine exhibited 90\% inhibition against the bacterium, with a MIC of $82.64 \mu \mathrm{g} / \mathrm{mL}$ [55].

Globospiramine, a new spirobisindole alkaloid that displayed significant antimycobacterial activity against Mycobacterium tuberculosis, was isolated from Voacanga globosa. This compound exhibited potent inhibitory activity against the bacterium, with a MIC of $4.00 \mu \mathrm{g} / \mathrm{mL}$ in a microplate Alamar blue assay and a MIC of $5.20 \mu \mathrm{g} / \mathrm{mL}$ in a low-oxygen recovery assay [56].

Ibogaine and voacangine were isolated from the plant Tabernaemontana citrifolia and were evaluated for their antimycobacterial activity against Mycobacterium tuberculosis. Both of these compounds displayed inhibitory effects against the bacterium, with MICs of $50.00 \mu \mathrm{g} / \mathrm{mL}$ for each (Figure 18) [57].

Voacamine is a bis-indole-type alkaloid isolated from the root of Tabernaemontana arborea. The compound showed inhibitory activity against the causative agent of tuberculosis, Mycobacterium tuberculosis. The results showed that the MIC and the $\mathrm{IC}_{50}$ values were 15.60 and $16.30 \mu \mathrm{g} / \mathrm{mL}$, respectively (Table 1, Figure 19) [58]. 


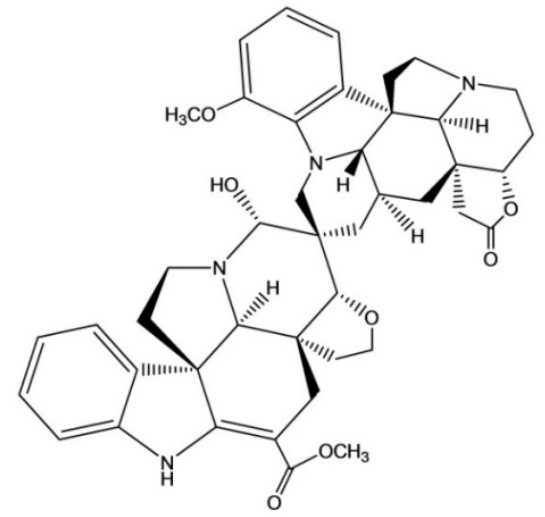

Globospiramine

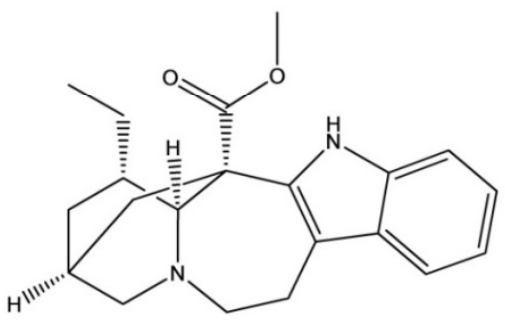

Coronaridine

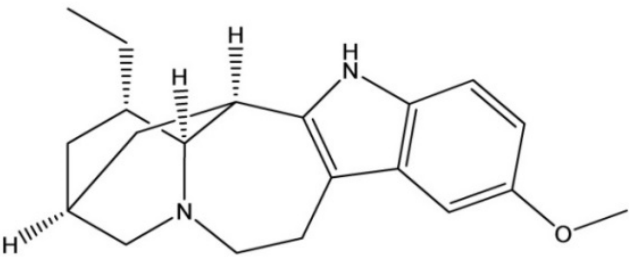

\section{Ibogaine}

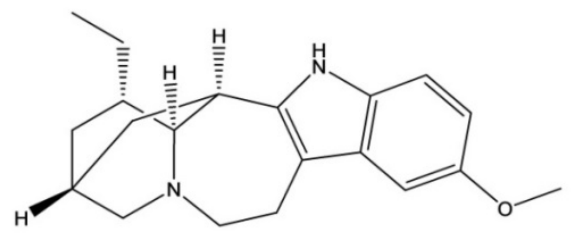

Ibogaine
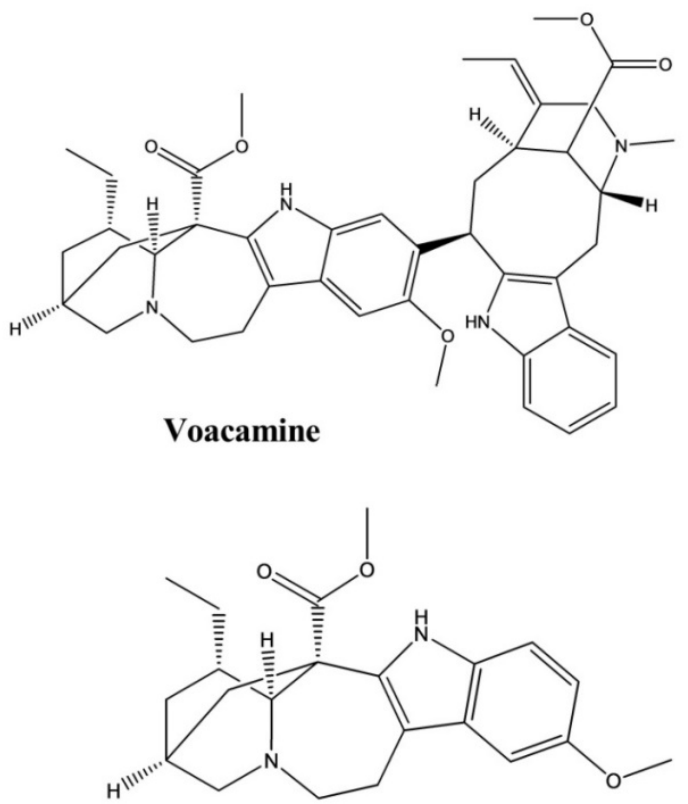

Voacangine

Figure 18. Antimycobacterial activity of indole alkaloids.

Table 1. Plant source and pharmacological activity of indole compounds.

\begin{tabular}{|c|c|c|c|c|c|c|}
\hline Compounds & Plant Source & $\begin{array}{c}\text { Posology } \\
\text { (Route, Dose) }\end{array}$ & Subject & Method & Identified Effect & References \\
\hline Scholarisine I, II, III, F & Alstonia rupestris & - & Fungi & $\begin{array}{l}\text { Disc diffusion } \\
\text { method }\end{array}$ & Antifungal & [5] \\
\hline Scholarisine I, VI & Alstonia rupestris & - & Enzyme & $\begin{array}{c}\text { Enzyme inhibition } \\
\text { assay }\end{array}$ & Anti-inflammatory & [5] \\
\hline Kopsihainin D, E, F & Kopsia hainanensis & - & Bacteria & $\begin{array}{l}\text { Disc agar diffusion } \\
\text { method }\end{array}$ & Antibacterial & [6] \\
\hline Kopsiflorine & Kopsia hainanensis & - & Bacteria & $\begin{array}{l}\text { Disc agar diffusion } \\
\text { method }\end{array}$ & Antibacterial & [6] \\
\hline Erchinine A, B & $\begin{array}{l}\text { Ervatamia } \\
\text { chinensis }\end{array}$ & - & $\begin{array}{l}\text { Bacteria } \\
\text { Fungus }\end{array}$ & $\begin{array}{l}\text { Broth microdilution } \\
\text { method }\end{array}$ & $\begin{array}{l}\text { Antibacterial, } \\
\text { Antifungal }\end{array}$ & [7] \\
\hline Melokhanine B, D, E, F & $\begin{array}{l}\text { Melodinus } \\
\text { khasianus }\end{array}$ & - & Bacteria & $\begin{array}{l}\text { Broth microdilution } \\
\text { method }\end{array}$ & Antibacterial & [8] \\
\hline Melokhanine B, D, E, F & $\begin{array}{l}\text { Melodinus } \\
\text { khasianus }\end{array}$ & - & Bacteria & $\begin{array}{l}\text { Broth microdilution } \\
\text { method }\end{array}$ & Antibacterial & [8] \\
\hline Strictamine & Alstonia scholaris & - & Virus & - & Antiviral & [9] \\
\hline 17-nor-excelsinidine & Alstonia scholaris & - & Virus & Microtiter & Antiviral & [9] \\
\hline Trigonoliimine & Trigonostemon lii & - & Virus & $\begin{array}{l}\text { syncytium } \\
\text { formation } \\
\text { infectivity assay }\end{array}$ & Antiviral & [10] \\
\hline Naucleaoffine A, B & Nauclea officinalis & & Virus & & Antiviral & [11] \\
\hline Mitragynine & Mitragyna speciosa & $\begin{array}{c}\text { Intraperitoneal, } \\
10 \text { and } \\
30 \mathrm{mg} / \mathrm{kg}\end{array}$ & Mice & $\begin{array}{l}\text { Forced swim test, } \\
\text { Tail suspension test }\end{array}$ & Antidepressant & [12] \\
\hline Lyaloside & Psychotria suterella & - & $\begin{array}{l}\text { Rat brain } \\
\text { mitochondria }\end{array}$ & Enzymatic assay & Antidepressant & [13] \\
\hline
\end{tabular}


Table 1. Cont

\begin{tabular}{|c|c|c|c|c|c|c|}
\hline Compounds & Plant Source & $\begin{array}{c}\text { Posology } \\
\text { (Route, Dose) }\end{array}$ & Subject & Method & Identified Effect & References \\
\hline Strictosamide & Psychotria laciniata & - & $\begin{array}{l}\text { Rat brain } \\
\text { mitochondria }\end{array}$ & Enzymatic assay & Antidepressant & [13] \\
\hline Harmane & Peganum harmala & $\begin{array}{l}\text { Intraperitoneal, } \\
5-15 \mathrm{mg} / \mathrm{kg}\end{array}$ & Mice & Forced swim test & Antidepressant & [14] \\
\hline Norharmane & Peganum harmala & $\begin{array}{l}\text { Intraperitoneal, } \\
2.5-10 \mathrm{mg} / \mathrm{kg}\end{array}$ & Mice & Forced swim test & Antidepressant & {$[14]$} \\
\hline Harmine & Peganum harmala & $\begin{array}{l}\text { Intraperitoneal, } \\
5-15 \mathrm{mg} / \mathrm{kg}\end{array}$ & Mice & Forced swim test & Antidepressant & [14] \\
\hline Psychollatine & $\begin{array}{c}\text { Psychotria } \\
\text { umbellate }\end{array}$ & $\begin{array}{l}3,7.5, \text { and } \\
15 \mathrm{mg} / \mathrm{kg}\end{array}$ & Mice & $\begin{array}{l}\text { Hole-board test, } \\
\text { Forced swim test }\end{array}$ & Antidepressant & [15] \\
\hline Tabersonine & $\begin{array}{l}\text { Melodinus } \\
\text { fusiformis }\end{array}$ & 0 & $\begin{array}{l}\text { Human } \\
\text { tumor cell } \\
\text { line }\end{array}$ & MTT assay & Anticancer & [16] \\
\hline Brucine & $\begin{array}{l}\text { Strychnos } \\
\text { nux-vomica }\end{array}$ & - & $\begin{array}{c}\text { Human } \\
\text { hepatoma cell } \\
\text { line }\end{array}$ & $\begin{array}{l}\text { MTT-colorimetric } \\
\text { assay }\end{array}$ & Anticancer & [17] \\
\hline Naucleaoral A, B & Nauclea orientalis & - & $\begin{array}{l}\text { Human } \\
\text { cancer cell } \\
\text { line }\end{array}$ & $\begin{array}{l}\text { MTT-colorimetric } \\
\text { assay }\end{array}$ & Anticancer & [18] \\
\hline Vallesiachotamine & $\begin{array}{l}\text { Anthocephalus } \\
\text { cadamba }\end{array}$ & - & $\begin{array}{l}\text { Human lung } \\
\text { cancer cell } \\
\text { line }\end{array}$ & MTT assay & Anticancer & [19] \\
\hline Iso-vallesiachotamine & $\begin{array}{l}\text { Anthocephalus } \\
\text { cadamba }\end{array}$ & - & $\begin{array}{l}\text { Human lung } \\
\text { cancer cell } \\
\text { line }\end{array}$ & MTT assay & Anticancer & [19] \\
\hline Ervachinine A, C, D & $\begin{array}{l}\text { Ervatamia } \\
\text { chinensis }\end{array}$ & - & $\begin{array}{l}\text { Human } \\
\text { cancer cell } \\
\text { line }\end{array}$ & MTT assay & Anticancer & {$[20]$} \\
\hline Jerantinine A, B & $\begin{array}{l}\text { Tabernaemontana } \\
\text { corymbosa }\end{array}$ & & $\begin{array}{l}\text { Human } \\
\text { cancer cell } \\
\text { line }\end{array}$ & MTT assay & Anticancer & [21] \\
\hline Melaxilline A, B & $\begin{array}{l}\text { Melodinus } \\
\text { axillaris. }\end{array}$ & - & Rat & $\begin{array}{l}\text { Platelet-activating } \\
\text { factor induced } \\
\text { inhibition assay }\end{array}$ & Anti-inflammatory & {$[22]$} \\
\hline Perakine $\mathrm{N}_{4}$-oxide & $\begin{array}{c}\text { Alstonia } \\
\text { yunnanensis. }\end{array}$ & - & Enzyme & $\begin{array}{l}\text { Enzyme inhibition } \\
\text { assay }\end{array}$ & Anti-inflammatory & [23] \\
\hline Raucaffrinoline $\mathrm{N}_{4}$-oxide & $\begin{array}{c}\text { Alstonia } \\
\text { yunnanensis. }\end{array}$ & - & Enzyme & $\begin{array}{l}\text { Enzyme inhibition } \\
\text { assay }\end{array}$ & Anti-inflammatory & [23] \\
\hline Vinorine $\mathrm{N}_{4}$-oxide & $\begin{array}{c}\text { Alstonia } \\
\text { yunnanensis. }\end{array}$ & Th & Enzyme & $\begin{array}{l}\text { Enzyme inhibition } \\
\text { assay }\end{array}$ & Anti-inflammatory & [23] \\
\hline Strictosamide & Nauclea officinalis & $\begin{array}{c}\text { Intraperitoneal, } \\
20 \text { and } \\
40 \mathrm{mg} / \mathrm{kg}\end{array}$ & Mice & $\begin{array}{l}\text { Hot plate test, } \\
\text { Writhing test }\end{array}$ & Analgesic & {$[24]$} \\
\hline Strictosamide & Psychotria laciniata & $\begin{array}{c}\text { Intravenous, } \\
20 \mathrm{and} \\
40 \mathrm{mg} / \mathrm{kg}\end{array}$ & Mice & $\begin{array}{l}\text { Acetic acid and } \\
\text { TPA-induced assay }\end{array}$ & Anti-inflammatory & {$[24]$} \\
\hline Brucine & $\begin{array}{l}\text { Strychnos } \\
\text { nux-vomica }\end{array}$ & $\begin{array}{c}\text { Intraperitoneal, } \\
30,15, \text { and } \\
7.5 \mathrm{mg} / \mathrm{kg}\end{array}$ & Mice & Formalin test & Analgesic & [25] \\
\hline Brucine & $\begin{array}{l}\text { Strychnos } \\
\text { nux-vomica }\end{array}$ & $\begin{array}{c}\text { Intraperitoneal, } \\
30,20,14.7 \text {, and } \\
10.3 \mathrm{mg} / \mathrm{kg}\end{array}$ & Mice & Hot plate test & Analgesic & [25] \\
\hline Brucine & $\begin{array}{l}\text { Strychnos } \\
\text { nux-vomica }\end{array}$ & $\begin{array}{c}\text { Intraperitoneal, } \\
30,15,7.5 \text {, and } \\
3.75 \mathrm{mg} / \mathrm{kg}\end{array}$ & Mice & Writhing test & Analgesic & [25] \\
\hline Brucine $\mathrm{N}$-oxide & $\begin{array}{l}\text { Strychnos } \\
\text { nux-vomica }\end{array}$ & $\begin{array}{l}\text { Intraperitoneal, } \\
200,100 \text { and } \\
50 \mathrm{mg} / \mathrm{kg}\end{array}$ & Mice & Formalin test & Analgesic & [25] \\
\hline Brucine $\mathrm{N}$-oxide & $\begin{array}{l}\text { Strychnos } \\
\text { nux-vomica }\end{array}$ & $\begin{array}{c}\text { Intraperitoneal, } \\
200,140,98, \\
\text { and } 68 \mathrm{mg} / \mathrm{kg}\end{array}$ & Mice & Hot plate test & Analgesic & [25] \\
\hline Brucine $\mathrm{N}$-oxide & $\begin{array}{l}\text { Strychnos } \\
\text { nux-vomica }\end{array}$ & $\begin{array}{c}\text { Intraperitoneal, } \\
200,100,50, \\
\text { and } 25 \mathrm{mg} / \mathrm{kg}\end{array}$ & Mice & Writhing test & Analgesic & [25] \\
\hline Mitragynine & Mitragyna speciosa & $\begin{array}{l}\text { Intraperitoneal, } \\
3-35 \mathrm{mg} / \mathrm{kg}\end{array}$ & Mice & Hot plate test & Analgesic & [26] \\
\hline 7-hydroxymitragynine & Mitragyna speciosa & $\begin{array}{l}\text { Subcutaneous, } \\
2.5-10 \mathrm{mg} / \mathrm{kg}\end{array}$ & Mice & $\begin{array}{c}\text { Hot plate test, Tail } \\
\text { flick test } \\
\text { Tail-flick test, }\end{array}$ & Analgesic & [27] \\
\hline Umbellatine & $\begin{array}{l}\text { Psychotria } \\
\text { umbellate }\end{array}$ & $100-300 \mathrm{mg} / \mathrm{kg}$ & Mice & $\begin{array}{c}\text { Hot-plate test, } \\
\text { Formalin test and } \\
\text { Capsaicin-induced } \\
\text { pain test }\end{array}$ & Analgesic & [28] \\
\hline Vindoline & $\begin{array}{l}\text { Catharanthus } \\
\text { roseus }\end{array}$ & - & $\begin{array}{l}\text { Enzyme, } \\
\text { Myoblast } \\
\text { cell }\end{array}$ & $\begin{array}{c}\text { Enzyme inhibition } \\
\text { assay, Glucose } \\
\text { uptake activity } \\
\text { assay }\end{array}$ & Antidiabetic & [29] \\
\hline
\end{tabular}


Table 1. Cont

\begin{tabular}{|c|c|c|c|c|c|c|}
\hline Compounds & Plant Source & $\begin{array}{c}\text { Posology } \\
\text { (Route, Dose) }\end{array}$ & Subject & Method & Identified Effect & References \\
\hline Vindolidine & $\begin{array}{l}\text { Catharanthus } \\
\text { roseus }\end{array}$ & - & $\begin{array}{l}\text { Enzyme, } \\
\text { Myoblast } \\
\text { cell }\end{array}$ & $\begin{array}{c}\text { Enzyme inhibition } \\
\text { assay, Glucose } \\
\text { uptake activity } \\
\text { assay }\end{array}$ & Antidiabetic & [29] \\
\hline Vindolicine & $\begin{array}{l}\text { Catharanthus } \\
\text { roseus }\end{array}$ & - & $\begin{array}{l}\text { Enzyme, } \\
\text { Myoblast } \\
\text { cell }\end{array}$ & $\begin{array}{c}\text { Enzyme inhibition } \\
\text { assay, Glucose } \\
\text { uptake activity } \\
\text { assay }\end{array}$ & Antidiabetic & [29] \\
\hline Vindolinine & $\begin{array}{l}\text { Catharanthus } \\
\text { roseus }\end{array}$ & - & $\begin{array}{l}\text { Enzyme, } \\
\text { Myoblast } \\
\text { cell }\end{array}$ & $\begin{array}{c}\text { Enzyme inhibition } \\
\text { assay, Glucose } \\
\text { uptake activity } \\
\text { assay }\end{array}$ & Antidiabetic & [29] \\
\hline Vindogentianine & $\begin{array}{l}\text { Catharanthus } \\
\text { roseus }\end{array}$ & - & $\begin{array}{l}\text { Enzyme, } \\
\text { Myoblast } \\
\text { cell }\end{array}$ & $\begin{array}{c}\text { Enzyme inhibition } \\
\text { assay, Glucose } \\
\text { uptake activity } \\
\text { assay }\end{array}$ & Antidiabetic & {$[30]$} \\
\hline Akuammicine & Picralima nitida & - & $\begin{array}{l}\text { Myoblast } \\
\text { cell }\end{array}$ & $\begin{array}{c}\text { Glucose uptake } \\
\text { activity assay }\end{array}$ & Antidiabetic & [31] \\
\hline Ellipticine & $\begin{array}{l}\text { Aspidosperma } \\
\text { vargasii }\end{array}$ & $\begin{array}{c}\text { Oral, } \\
\text { Subcutaneous, } \\
50,10 \text { and } \\
1 \mathrm{mg} / \mathrm{kg} / \text { day }\end{array}$ & Mice & Suppressive test & Antimalarial & [32] \\
\hline Olivacine & $\begin{array}{l}\text { Aspidosperma } \\
\text { olivaceum. }\end{array}$ & $\begin{array}{c}\text { Oral, } \\
\text { Subcutaneous, } \\
100,50,10 \text {, and } \\
1 \mathrm{mg} / \mathrm{kg} / \text { day }\end{array}$ & Mice & Suppressive test & Antimalarial & {$[32]$} \\
\hline Flinderole A, B, C & $\begin{array}{c}\text { Flindersia } \\
\text { acuminate } \\
\text { F. amboinensis }\end{array}$ & 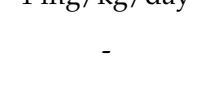 & $\begin{array}{l}\text { Malarial } \\
\text { Parasite }\end{array}$ & $\begin{array}{l}\text { Micrdilution } \\
\text { method }\end{array}$ & Antimalarial & {$[33]$} \\
\hline Apisdospermin & & - & $\begin{array}{l}\text { Malarial } \\
\text { Parasite }\end{array}$ & $\begin{array}{l}\text { Micrdilution } \\
\text { method }\end{array}$ & Antimalarial & [34] \\
\hline Aspidospermine & $\begin{array}{l}\text { Aspidosperma } \\
\text { pyrifolium }\end{array}$ & - & $\begin{array}{l}\text { Malarial } \\
\text { Parasite }\end{array}$ & $\begin{array}{l}\text { Micrdilution } \\
\text { method }\end{array}$ & Antimalarial & [34] \\
\hline $\begin{array}{c}\text { Demethoxy- } \\
\text { aspidospermine }\end{array}$ & $\begin{array}{l}\text { Aspidosperma } \\
\text { pyrifolium }\end{array}$ & - & $\begin{array}{l}\text { Malarial } \\
\text { Parasite }\end{array}$ & $\begin{array}{l}\text { Micrdilution } \\
\text { method }\end{array}$ & Antimalarial & [34] \\
\hline Vallesine & $\begin{array}{l}\text { Aspidosperma } \\
\text { pyrifolium }\end{array}$ & - & $\begin{array}{l}\text { Malarial } \\
\text { Parasite }\end{array}$ & $\begin{array}{l}\text { Micrdilution } \\
\text { method }\end{array}$ & Antimalarial & {$[34]$} \\
\hline Palosine & $\begin{array}{l}\text { Aspidosperma } \\
\text { pyrifolium }\end{array}$ & - & $\begin{array}{l}\text { Malarial } \\
\text { Parasite }\end{array}$ & $\begin{array}{l}\text { Micrdilution } \\
\text { method }\end{array}$ & Antimalarial & {$[34]$} \\
\hline Geissolosimine & $\begin{array}{l}\text { Geissospermum } \\
\text { vellosii }\end{array}$ & - & $\begin{array}{l}\text { Malarial } \\
\text { Parasite }\end{array}$ & $\begin{array}{c}\text { Parasite lactate } \\
\text { dehydrogenase } \\
\text { assay }\end{array}$ & Antimalarial & [35] \\
\hline Geissospermine & $\begin{array}{c}\text { Geissospermum } \\
\text { vellosii }\end{array}$ & - & $\begin{array}{l}\text { Malarial } \\
\text { Parasite }\end{array}$ & $\begin{array}{l}\text { Parasite lactate } \\
\text { dehydrogenase } \\
\text { assay }\end{array}$ & Antimalarial & {$[35]$} \\
\hline Geissoschizoline & $\begin{array}{l}\text { Geissospermum } \\
\text { vellosii }\end{array}$ & - & $\begin{array}{l}\text { Malarial } \\
\text { Parasite }\end{array}$ & $\begin{array}{c}\text { Parasite lactate } \\
\text { dehydrogenase } \\
\text { assay }\end{array}$ & Antimalarial & [35] \\
\hline Geissoschizone & $\begin{array}{l}\text { Geissospermum } \\
\text { vellosii }\end{array}$ & - & $\begin{array}{l}\text { Malarial } \\
\text { Parasite }\end{array}$ & $\begin{array}{l}\text { Parasite lactate } \\
\text { dehydrogenase } \\
\text { assay }\end{array}$ & Antimalarial & [35] \\
\hline Naucline & $\begin{array}{l}\text { Nauclea } \\
\text { officinalis }\end{array}$ & $\begin{array}{c}\text { Injection, } \\
1 \times 10^{-5} \mathrm{M}\end{array}$ & Rat & $\begin{array}{c}\text { Phenylephrine- } \\
\text { induced } \\
\text { vasodilation assay }\end{array}$ & Hypotensive & [36] \\
\hline Angustine & $\begin{array}{l}\text { Nauclea } \\
\text { officinalis }\end{array}$ & $\begin{array}{c}\text { Injection, } \\
1 \times 10^{-5} \mathrm{M}\end{array}$ & Rat & $\begin{array}{c}\text { Phenylephrine- } \\
\text { induced } \\
\text { vasodilation assay }\end{array}$ & Hypotensive & [36] \\
\hline Angustidine & $\begin{array}{l}\text { Nauclea } \\
\text { officinalis }\end{array}$ & $\begin{array}{c}\text { Injection, } \\
1 \times 10^{-5} \mathrm{M}\end{array}$ & Rat & $\begin{array}{c}\text { Phenylephrine- } \\
\text { induced } \\
\text { vasodilation assay }\end{array}$ & Hypotensive & [36] \\
\hline Nauclefine & $\begin{array}{l}\text { Nauclea } \\
\text { officinalis }\end{array}$ & $\begin{array}{c}\text { Injection, } \\
1 \times 10^{-5} \mathrm{M}\end{array}$ & Rat & $\begin{array}{c}\text { Phenylephrine- } \\
\text { induced } \\
\text { vasodilation assay }\end{array}$ & Hypotensive & [36] \\
\hline Naucletine & $\begin{array}{l}\text { Nauclea } \\
\text { officinalis }\end{array}$ & $\begin{array}{c}\text { Injection, } \\
1 \times 10^{-5} \mathrm{M}\end{array}$ & Rat & $\begin{array}{c}\text { Phenylephrine- } \\
\text { induced } \\
\text { vasodilation assay }\end{array}$ & Hypotensive & [36] \\
\hline Alstilobanine A, B, C & $\begin{array}{c}\text { Alstonia } \\
\text { angustiloba }\end{array}$ & - & Rat & $\begin{array}{l}\text { Phenylephrine- } \\
\text { induced } \\
\text { vasodilation assay }\end{array}$ & Hypotensive & [37] \\
\hline Undulifoline & $\begin{array}{c}\text { Alstonia } \\
\text { undulifolia }\end{array}$ & - & Rat & $\begin{array}{c}\text { Phenylephrine- } \\
\text { induced } \\
\text { vasodilation assay }\end{array}$ & Hypotensive & [37] \\
\hline Taberniacin A, B & $\begin{array}{c}\text { Tabernaemontana } \\
\text { divaricata }\end{array}$ & - & Rat & $\begin{array}{l}\text { Phenylephrine- } \\
\text { induced } \\
\text { vasodilation assay }\end{array}$ & Hypotensive & [38] \\
\hline Villocarine A & Uncaria villosa & $\begin{array}{l}\text { Injection, } \\
30 \mu \mathrm{M}\end{array}$ & Rat & $\begin{array}{c}\text { Phenylephrine- } \\
\text { induced } \\
\text { vasodilation assay }\end{array}$ & Hypotensive & [39] \\
\hline Macusine B & Rauvolfia reflexa & - & $\begin{array}{l}\text { Cholinesterase } \\
\text { Enzyme }\end{array}$ & $\begin{array}{l}\text { Cholinesterase } \\
\text { Inhibition assay }\end{array}$ & Anticholinesterase & {$[40]$} \\
\hline Vinorine & Rauvolfia reflexa & - & $\begin{array}{l}\text { Cholinesterase } \\
\text { Enzyme }\end{array}$ & $\begin{array}{l}\text { Cholinesterase } \\
\text { Inhibition assay }\end{array}$ & Anticholinesterase & {$[40]$} \\
\hline
\end{tabular}


Table 1. Cont

\begin{tabular}{|c|c|c|c|c|c|c|}
\hline Compounds & Plant Source & $\begin{array}{c}\text { Posology } \\
\text { (Route, Dose) }\end{array}$ & Subject & Method & Identified Effect & References \\
\hline Isoreserpiline & Rauvolfia reflexa & - & $\begin{array}{l}\text { Cholinesterase } \\
\text { Enzyme }\end{array}$ & $\begin{array}{l}\text { Cholinesterase } \\
\text { Inhibition assay }\end{array}$ & Anticholinesterase & {$[40]$} \\
\hline Rescinnamine & Rauvolfia reflexa & - & $\begin{array}{l}\text { Cholinesterase } \\
\text { Enzyme }\end{array}$ & $\begin{array}{l}\text { Cholinesterase } \\
\text { Inhibition assay }\end{array}$ & Anticholinesterase & {$[40]$} \\
\hline $\begin{array}{c}\text { Voacangine } \\
\text { hydroxyindolenine }\end{array}$ & $\begin{array}{c}\text { Tabernaemontana } \\
\text { australis }\end{array}$ & - & $\begin{array}{l}\text { Cholinesterase } \\
\text { Enzyme }\end{array}$ & $\begin{array}{l}\text { Cholinesterase } \\
\text { Inhibition assay }\end{array}$ & Anticholinesterase & [41] \\
\hline Rupicoline & $\begin{array}{c}\text { Tabernaemontana } \\
\text { australis }\end{array}$ & - & $\begin{array}{l}\text { Cholinesterase } \\
\text { Enzyme }\end{array}$ & $\begin{array}{l}\text { Cholinesterase } \\
\text { Inhibition assay }\end{array}$ & Anticholinesterase & [41] \\
\hline Coronaridine & $\begin{array}{l}\text { Ervatamia } \\
\text { hainanensis }\end{array}$ & - & $\begin{array}{l}\text { Cholinesterase } \\
\text { Enzyme }\end{array}$ & $\begin{array}{l}\text { Cholinesterase } \\
\text { Inhibition assay }\end{array}$ & Anticholinesterase & {$[42]$} \\
\hline Voacangine & $\begin{array}{l}\text { Ervatamia } \\
\text { hainanensis }\end{array}$ & - & $\begin{array}{l}\text { Cholinesterase } \\
\text { Enzyme }\end{array}$ & $\begin{array}{l}\text { Cholinesterase } \\
\text { Inhibition assay }\end{array}$ & Anticholinesterase & {$[42]$} \\
\hline Angustidine & Nauclea officinalis & - & $\begin{array}{l}\text { Cholinesterase } \\
\text { Enzyme }\end{array}$ & $\begin{array}{l}\text { Cholinesterase } \\
\text { Inhibition assay }\end{array}$ & Anticholinesterase & {$[43]$} \\
\hline Nauclefine & Nauclea officinalis & - & $\begin{array}{l}\text { Cholinesterase } \\
\text { Enzyme }\end{array}$ & $\begin{array}{l}\text { Cholinesterase } \\
\text { Inhibition assay }\end{array}$ & Anticholinesterase & {$[43]$} \\
\hline Angustine & Nauclea officinalis & - & $\begin{array}{l}\text { Cholinesterase } \\
\text { Enzyme }\end{array}$ & $\begin{array}{l}\text { Cholinesterase } \\
\text { Inhibition assay }\end{array}$ & Anticholinesterase & {$[43]$} \\
\hline Harmane & Perganum harmala & $100-200 \mu \mathrm{M}$ & $\begin{array}{l}\text { Rabbit } \\
\text { Platelet }\end{array}$ & - & Antiplatelet & {$[44]$} \\
\hline Harmine & Perganum harmala & $100-200 \mu \mathrm{M}$ & $\begin{array}{l}\text { Rabbit } \\
\text { Platelet }\end{array}$ & - & Antiplatelet & {$[44]$} \\
\hline Harmol & Perganum harmala & $100-200 \mu \mathrm{M}$ & $\begin{array}{l}\text { Rabbit } \\
\text { Platelet }\end{array}$ & 0 & Antiplatelet & {$[44]$} \\
\hline Kurryam & Murraya koenigii & $\begin{array}{l}10,30, \text { and } \\
50 \mathrm{mg} / \mathrm{kg}\end{array}$ & Rat & $\begin{array}{c}\text { Castor oil-induced } \\
\text { test }\end{array}$ & Antidiarrheal & {$[45]$} \\
\hline Koenimbine & Murraya koenigii & $\begin{array}{l}10,30, \text { and } \\
50 \mathrm{mg} / \mathrm{kg}\end{array}$ & Rat & $\begin{array}{c}\text { Castor oil-induced } \\
\text { test } \\
\text { Castor oil, }\end{array}$ & Antidiarrheal & {$[45]$} \\
\hline Bisnordihydrotoxiferine & Strychnos trinervis & $\begin{array}{l}\text { Intraperitoneal, } \\
3.12-25.00 \mathrm{mg} / \mathrm{kg}\end{array}$ & Rat, Mice & $\begin{array}{l}\text { Magnesium sulfate, } \\
\text { and Arachidonic } \\
\text { acid-induced } \\
\text { diarrhea test }\end{array}$ & Antidiarrheal & [46] \\
\hline Trinervine & Strychnos trinervis & - & $\begin{array}{l}\text { Rat fundic } \\
\text { strip, } \\
\text { Guinea-pig } \\
\text { ileum }\end{array}$ & $\begin{array}{l}\text { Arachidonic acid, 5- } \\
\text { hydroxytryptamine, } \\
\text { Histamine, and } \\
\text { Carbachol mediated } \\
\text { contractions } \\
\text { Acetylcholine, }\end{array}$ & Spasmolytic & [47] \\
\hline Bisnordihydrotoxiferine & $\begin{array}{l}\text { Strychnos } \\
\text { diuaricuns }\end{array}$ & - & $\begin{array}{l}\text { Rat uterus } \\
\text { Guinea-pig } \\
\text { ileum }\end{array}$ & $\begin{array}{l}\text { Oxytocin-induced } \\
\text { contraction, and } \\
\text { Histamine-induced } \\
\text { contractions }\end{array}$ & Spasmolytic & {$[48]$} \\
\hline Normacusine B & Strychnos atlantica & $\begin{array}{l}0.1,0.3,1.0 \text {, and } \\
3.0 \mu \mathrm{M}\end{array}$ & Rat aorta & $\begin{array}{l}\text { Phenylephrine and } \\
\text { Serotonin-induced } \\
\text { contractions. } \\
\text { Histamine, }\end{array}$ & Spasmolytic & [49] \\
\hline Harmine & Perganum harmala & $1-100 \mu \mathrm{M}$ & $\begin{array}{l}\text { Guinea-Pig } \\
\text { Trachea }\end{array}$ & $\begin{array}{l}\text { Carbachol, and } \\
\text { KCl-induced } \\
\text { contractions }\end{array}$ & Spasmolytic & {$[50]$} \\
\hline Harmane & Perganum harmala & $1-100 \mu \mathrm{M}$ & $\begin{array}{l}\text { Guinea-Pig } \\
\text { Trachea }\end{array}$ & $\begin{array}{l}\text { Histamine, } \\
\text { Carbachol, and } \\
\text { KCl-induced } \\
\text { contractions } \\
\text { Histamine, }\end{array}$ & Spasmolytic & {$[50]$} \\
\hline Harmaline & Perganum harmala & $1-100 \mathrm{Mm}$ & $\begin{array}{l}\text { Guinea-Pig } \\
\text { Trachea }\end{array}$ & $\begin{array}{l}\text { Carbachol, and } \\
\text { KCl-induced } \\
\text { contractions }\end{array}$ & Spasmolytic & {$[50]$} \\
\hline Ramiflorine A, B & $\begin{array}{l}\text { Aspidosperma } \\
\text { ramiflorum }\end{array}$ & - & Parasite & & Antileishmanial & {$[51]$} \\
\hline Ellipticine & Ochrosia borbonica & $0.01-10 \mu \mathrm{mol} \cdot \mathrm{L}^{-1}$ & $\begin{array}{l}\text { Mouse } \\
\text { fibroblast } \\
\text { cells }\end{array}$ & Triglyceride assay & Lipid-lowering & {$[52]$} \\
\hline 9-methoxyellipticine & Ochrosia borbonica & $0.01-10 \mu \mathrm{mol} \cdot \mathrm{L}^{-1}$ & $\begin{array}{l}\text { Mouse } \\
\text { fibroblast } \\
\text { cells }\end{array}$ & Triglyceride assay & Lipid-lowering & [52] \\
\hline Vincamine & Vinca minor & $\begin{array}{c}\text { Oral, } \\
20 \text { and } \\
30 \mathrm{mg} / \mathrm{kg}\end{array}$ & Rat & & Lipid-lowering & {$[53,54]$} \\
\hline Coronaridine & $\begin{array}{c}\text { Tabernaemontana } \\
\text { ternifolia }\end{array}$ & - & Bacteria & $\begin{array}{l}\text { Microplate Alamar } \\
\text { blue assay }\end{array}$ & Antimycobacterial & {$[55]$} \\
\hline Globospiramine & Voacanga globosa & - & Bacteria & $\begin{array}{l}\text { Microplate Alamar } \\
\text { blue assay and } \\
\text { Low-oxygen } \\
\text { recovery assay }\end{array}$ & Antimycobacterial & {$[56]$} \\
\hline Ibogaine & $\begin{array}{l}\text { Tabernaemontana } \\
\text { citrifolia }\end{array}$ & - & Bacteria & $\begin{array}{l}\text { Bactec radiometric } \\
\text { methodology }\end{array}$ & Antimycobacterial & [57] \\
\hline Voacangine & $\begin{array}{l}\text { Tabernaemontana } \\
\text { citrifolia }\end{array}$ & - & Bacteria & $\begin{array}{l}\text { Bactec radiometric } \\
\text { methodology }\end{array}$ & Antimycobacterial & [57] \\
\hline Voacamine & $\begin{array}{c}\text { Tabernaemontana } \\
\text { arborea. }\end{array}$ & - & Bacteria & $\begin{array}{l}\text { Resazurin } \\
\text { microtiter assay }\end{array}$ & Antimycobacterial & {$[58]$} \\
\hline
\end{tabular}




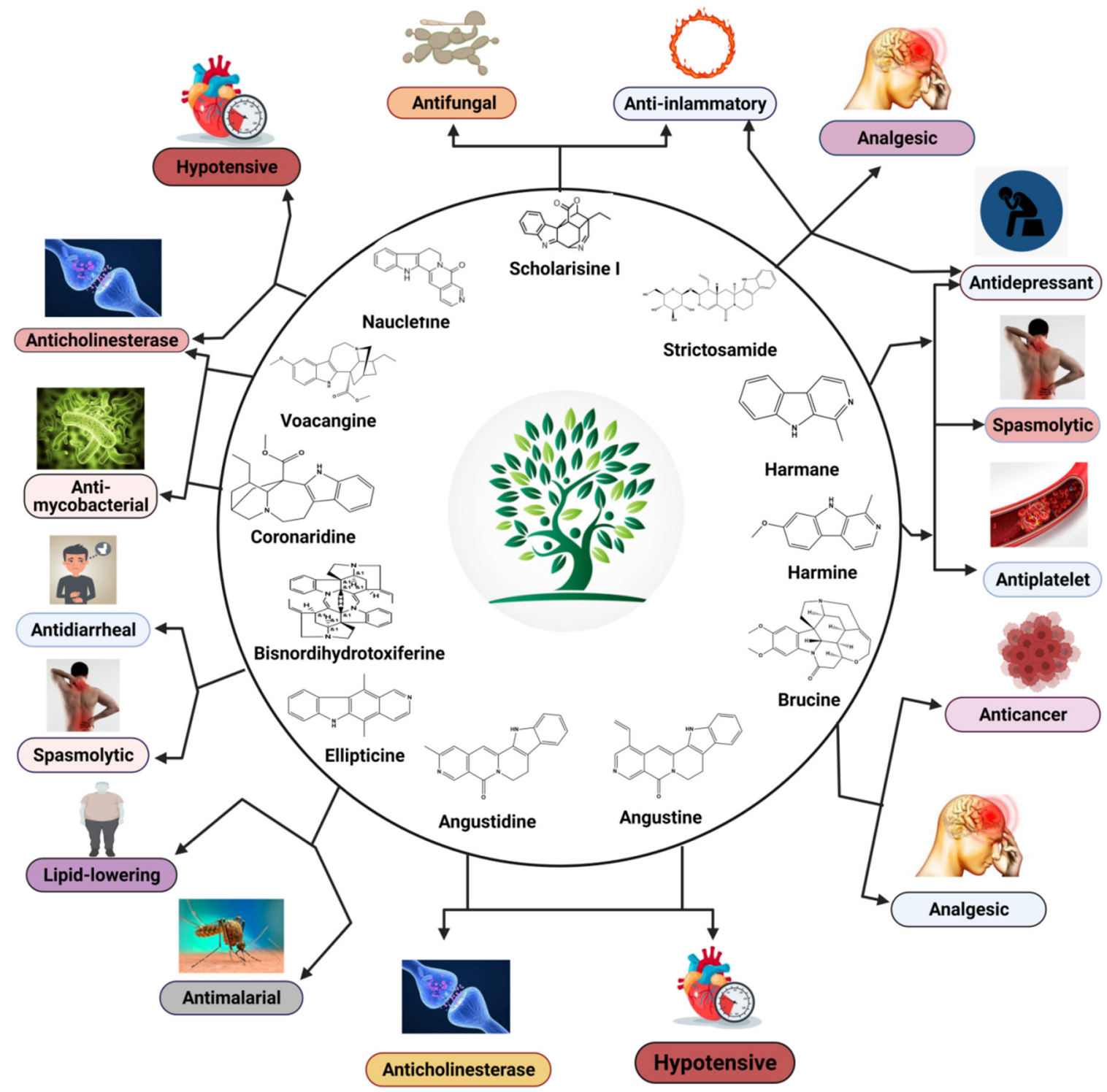

Figure 19. An overview of the pharmacological activities of major indole alkaloids.

\section{Pharmacokinetic Profile}

A pharmacokinetics (pk) study of a compound describes four basic phenomena that occur when a foreign substance (xenobiotic) enters the body: absorption, distribution, metabolism or biotransformation, and excretion. The kinetics of these four phenomena help researchers understand, analyze, and predict the biological activities of xenobiotics [59].

Absorption describes the process through which a drug enters the body's circulation at the site of administration across biological membranes. The rate and extent of absorption depend on the route and the site of administration, and the chemical properties of the drug. Absorption directly affects the bioavailability of substances in the blood and can occur through various mechanisms, including passive and facilitated diffusion, active transport, endocytosis, and exocytosis. Distribution is the next step, during which substances from the bloodstream enter into tissues. Distribution is affected by cardiac output, local blood flow, capillary permeability, tissue volume, regional $\mathrm{pH}$, the degree of plasma binding, and the substances' relative lipophilicity. Metabolism is a fundamental process through which a substance is chemically altered within the body to facilitate excretion, which typically occurs in the liver. Metabolism involves Phase I and Phase II reactions. Although the 
primary goal of this process is to facilitate excretion, metabolism can convert the active form of a substance into an inactive form or activate a previously inactive form, as in the case of prodrugs. After metabolism, substances leave the body through a process known as excretion, which can occur through many methods, including in urine, feces, sweat, milk, and expired air.

Some of the compounds reviewed in this article were subjected to pk studies (Table 2).

Table 2. Pharmacokinetic profiles of indole alkaloids.

\begin{tabular}{|c|c|c|c|c|c|}
\hline \multirow[b]{2}{*}{ Parameters } & \multicolumn{5}{|c|}{ Compound Name } \\
\hline & Brucine & Harmane & Vindoline & Mitragynine & 7-OH-mitragynine \\
\hline $\begin{array}{l}\text { Administration } \\
\text { Route }\end{array}$ & Oral, IV & Oral, IV & Oral, IV & Oral & Oral \\
\hline Oral Bioavailability & $40.31 \%-47.15 \%$ & $19.41 \%$ & $5.4 \%$ & - & - \\
\hline AUC & Ratio: 1:1.9:5.3 (at different doses) & - & $\begin{array}{c}\text { Oral: } 606.3 \mathrm{ng} / \mathrm{mL} \mathrm{h,} \\
\text { IV: } 2245.7 \text { (first dose), } \\
2258.0 \text { (second dose) } \mathrm{ng} / \mathrm{mL} \mathrm{h}\end{array}$ & - & - \\
\hline $\mathrm{C}_{\max }$ & $929.22-1451.58 \mu \mathrm{g} / \mathrm{L}$ & $\begin{aligned} & \text { Oral: } 1059.56 \pm 91.06 \mathrm{ng} / \mathrm{mL} \text {, } \\
& \text { IV: } 583.19 \mathrm{ng} / \mathrm{mL}\end{aligned}$ & $\begin{array}{c}\text { Oral: } 606.6 \mathrm{ng} / \mathrm{mL} \\
\text { IV: } 1595.9 \text { (first dose), } \\
2913.9 \mathrm{ng} / \mathrm{mL} \text { (second dose) }\end{array}$ & $0.63 \pm 0.18 \mu \mathrm{g} / \mathrm{mL}$ & - \\
\hline $\mathrm{T}_{\max }$ & $0.3-0.5 \mathrm{~h}$ & $\begin{array}{l}\text { Oral: } 0.23 \pm 0.06 \mathrm{~h}, \\
\text { IV: } 0.03 \mathrm{~h}\end{array}$ & Oral: $0.3 \mathrm{~h}$ & $1.83 \pm 1.25 \mathrm{~h}$ & - \\
\hline$t_{1 / 2}$ & - & (2) & $\begin{array}{c}\text { Oral: } 0.5 \mathrm{~h} \\
\text { IV: } 1.0 \mathrm{~h} \text { (first dose), } \\
\text { 1.4 h (second dose) } \\
\text { Oral; } 21.6 \mathrm{~L} / \mathrm{kg}\end{array}$ & - & $24 \mathrm{~min}$ \\
\hline $\mathrm{V}_{\mathrm{d}}$ & - & - & $\begin{array}{l}\text { IV: } 2.0 \mathrm{~L} / \mathrm{kg} \text { (first dose), } \\
3.3 \mathrm{~L} / \mathrm{kg} \text { (second dose) } \\
\text { Oral: } 26.6 \mathrm{~L} / \mathrm{h} / \mathrm{kg}\end{array}$ & $89.50 \pm 30.30 \mathrm{~L} / \mathrm{kg}$ & - \\
\hline $\mathrm{CL}$ & - & - & $\begin{array}{l}\text { IV: } 1.4 \mathrm{~L} / \mathrm{h} / \mathrm{kg} \text { (first dose), } \\
1.4 \mathrm{~L} / \mathrm{h} / \mathrm{kg} \text { (second dose) }\end{array}$ & - & $43.2 \pm 3.5 \mathrm{~mL} / \mathrm{min} / \mathrm{kg}$ \\
\hline References & {$[60]$} & {$[64]$} & [63] & [61] & [62] \\
\hline
\end{tabular}

Brucine is among the major indole alkaloids with various potent pharmacological activities. The pk properties of brucine were investigated after intravenous and oral administration to rats, which resulted in some significant outcomes. The determination of the apparent partition coefficient, plasma protein binding, and other pk properties were evaluated. Brucine showed no sign of degradation in gastrointestinal $\mathrm{pH}$ conditions, and the total concentration of the drug in both the water and oil phase did not change after $2 \mathrm{~h}$ of incubation at $\mathrm{pH} 1-7.8$, indicating relative stability under acidic conditions. The $\mathrm{pH}$ has a substantial effect on the apparent partition coefficient, particularly in the range of $\mathrm{pH}$ 6-7.8. Brucine showed a partition coefficient below 0.1 due to complete protonation at $\mathrm{pH}$ 1-5. The apparent partition coefficient of brucine under different $\mathrm{pH}$ conditions indicated that the most likely absorption site was the intestine because brucine became ionized under stomach-like $\mathrm{pH}$ conditions. The protein binding assay revealed that the majority of brucine was primarily bound to the rat plasma protein, with the unbound fraction representing $34.4 \% \pm 3.0 \%, 35.1 \% \pm 2.9 \%$, and $40.4 \% \pm 2.7 \%$ of the total at treatment concentrations of 500, 1250, and $2500 \mu \mathrm{g} / \mathrm{L}$, respectively. After administering single intravenous doses of 2.5,5, and $10 \mathrm{mg} / \mathrm{kg}$, the ratio of the mean area under the curve (AUC) values was 1:1.9:5.3 when the dose increased at a ratio of 1:2:4. The total body clearance drastically decreased at the $10 \mathrm{mg} / \mathrm{kg}$ dose, whereas the terminal elimination half-life (T1/2) increased in a dose-dependent fashion. Brucine was rapidly absorbed (Tmax $=0.3-0.5 \mathrm{~h}$ ) and achieved a mean maximum serum concentration (Cmax) between 929.22 and $1451.58 \mu \mathrm{g} / \mathrm{L}$ after oral administration. The absolute oral bioavailability was $40.31 \%-47.15 \%$. The increase in AUC was proportional to the increase in dose. Both the oral and intravenous administration routes for brucine showed non-linear $\mathrm{pk}$ properties overall [60].

A single dose of $40 \mathrm{mg}$ mitragynine ( $\mathrm{kg} /$ body $\mathrm{wt}$.) was given to six rats, and a non-compartmental pk analysis was performed. Mitragynine was rapidly absorbed after oral administration, reaching a Cmax of $0.63 \pm 0.18 \mu \mathrm{g} / \mathrm{mL}$ at $1.83 \pm 1.25 \mathrm{~h}$ (Tmax), with an absorption rate constant $(\mathrm{ka})$ of $1.43 \pm 0.90 \mathrm{~h}-1$. Mitragynine showed a high volume of distribution $(\mathrm{Vd} / \mathrm{F}, 89.50 \pm 30.30 \mathrm{~L} / \mathrm{kg}$ ) due to distribution into highly perfused and lipid-containing tissues, specifically the brain, which is the site of action for mitragynine. Mitragynine displayed a slow elimination, with an elimination rate constant $(\lambda z)$ of 
$0.07 \pm 0.01 \mathrm{~h}^{-1}$ and a clearance rate $(\mathrm{Cl} / \mathrm{F})$ of $1.60 \pm 0.58 \mathrm{~L} / \mathrm{h}$. The half-lives of absorption $(\mathrm{t} 1 / 2 \mathrm{ab})$ and elimination $(\mathrm{t} 1 / 2 \lambda \mathrm{z})$ were $0.48 \pm 0.36$ and $9.43 \pm 1.74 \mathrm{~h}$, respectively. The mean residence time (MRT0 $\rightarrow \infty$ ) was $14.00 \pm 2.84 \mathrm{~h}$ [61]. Another study showed that mitragynine experienced $26 \%$ degradation in simulated gastric fluid, indicating that mitragynine was unstable in gastric fluid, whereas stability was demonstrated in simulated intestinal fluid. Another mitragynine-like compound, 7-hydroxymitragynine, was degraded by up to $27 \%$ in simulated gastric juice, which might be due to conversion to mitragynine (23\%), whereas only $6 \%$ degradation was observed in simulated intestinal fluid. Both of these compounds exhibited greater than $90 \%$ protein binding, as determined by the equilibrium analysis. In addition, 7-hydroxymitragynine was shown to have moderate intestinal and blood-brain barrier (BBB) permeability with a significant conversion to mitragynine. It showed an intermediate level of intestinal absorption. It was rapidly metabolized by Phase I metabolic enzymes, with a short T1/2 of $24 \mathrm{~min}$. The high clearance of $43.2 \pm 3.5 \mathrm{~mL} / \mathrm{min} / \mathrm{kg}$ in the presence of human liver microsomes results in low bioavailability and limited distribution to tissues. Mitragynine and 7-hydroxymitragynine exhibited significant P-gp (P-glycoprotein) inhibition, similar to verapamil, indicating the possibility of drug-drug interactions when coadministered with drugs that are P-gp substrates [62].

The pk study of vindoline was characterized by the use of a non-compartmental method. Doses of $15 \mathrm{mg} / \mathrm{kg}$ (oral), $3 \mathrm{mg} / \mathrm{kg}$ (IV), and $6 \mathrm{mg} / \mathrm{kg}$ (IV) of vindoline were administered to rats. The area under the plasma concentration-time curves, AUC (0-t) and AUC (0- $\infty$,) were 606.3 and $609.1 \mathrm{ng} / \mathrm{mL} \mathrm{h}$, respectively for the oral dose, 2245.7 and $3776.2 \mathrm{ng} / \mathrm{mL} \mathrm{h}$ for the low-dose IV administration, and 2258.0 and $3788.4 \mathrm{ng} / \mathrm{mL} \mathrm{h}$ for the high-dose IV administration. For the oral dose, the T1/2, the plasma clearance (CL), and the apparent volume of distribution $(\mathrm{V})$ were $0.5 \mathrm{~h}, 26.6 \mathrm{~L} / \mathrm{h} / \mathrm{kg}$, and $21.6 \mathrm{~L} / \mathrm{kg}$, respectively. For the IV doses, the $\mathrm{T} 1 / 2, \mathrm{CL}$, and $\mathrm{V}$ values were $1.0 \mathrm{~h}, 1.4 \mathrm{~L} / \mathrm{h} / \mathrm{kg}$, and $2.0 \mathrm{~L} / \mathrm{kg}$, respectively, for the $3 \mathrm{mg} / \mathrm{kg}$ concentration and $1.4 \mathrm{~h}, 1.6 \mathrm{~L} / \mathrm{h} / \mathrm{kg}$, and $3.3 \mathrm{~L} / \mathrm{kg}$ for the $6 \mathrm{mg} / \mathrm{kg}$ concentration, indicating a dose-dependent increase in these parameters. The Cmax and Tmax were calculated, resulting in values of $606.6 \mathrm{ng} / \mathrm{mL}$ and $0.3 \mathrm{~h}$, respectively, for the oral dose. For the IV vindoline administration, a dose-dependent increase in Cmax was observed, with values of 1595.9 and $2913.9 \mathrm{ng} / \mathrm{mL}$, respectively, observed for the 3 and $6 \mathrm{mg} / \mathrm{kg}$ concentrations. The bioavailability of vindoline after oral administration was 5.4\% [63].

Harmane was immediately absorbed into the blood circulation, with a high Cmax of $1059.56 \pm 91.06 \mathrm{ng} / \mathrm{mL}$ and a short Tmax of $0.23 \pm 0.06 \mathrm{~h}$ after the administration of a single oral dose at $30.0 \mathrm{mg} / \mathrm{kg}$ body weight in rats. The plasma concentration-time curve for harmane displayed a rapid decrease, with an elimination half-life (T1/2e) of $2.26 \pm 0.53 \mathrm{~h}$, and the levels fell below the detection limits within $8 \mathrm{~h}$ after administration. The oral bioavailability of harmane was $19.41 \%$. The absorption rate constant $(\mathrm{Ka})$, distribution rate constant $(\mathrm{Kd})$, and elimination rate constant $(\mathrm{Ke})$ were $3.64,1.51$, and 0.32 per hour. Other parameters were also evaluated in that study. After an intravenous bolus administration of harmane at a dose of $1.0 \mathrm{mg} / \mathrm{kg}$, the harmane plasma concentration versus time curve yielded a sharp decline in the concentration, followed by a fast phase of decrease, with a $\mathrm{T} 1 / 2 \mathrm{e}$ of $4.71 \pm 1.46 \mathrm{~h}$, until the levels fell below the detection limits. The volume of distribution $(\mathrm{Vd})$ value for harmane was relatively high. The Cmax value was $583.19 \mathrm{ng} / \mathrm{mL}$ at a Tmax of $0.03 \mathrm{~h}$. The Ka, Kd, and Ke values were 4.18, 1.54, and 0.16 per hour. The metabolic process for harmane was also determined, and sulfate conjugation appeared to be the most prominent process [64].

\section{Conclusions and Future Perspectives}

Indole alkaloids of plant origin have demonstrated diverse potential pharmacological activities; therefore, we reviewed various indole compounds and discussed their respective pharmacological importance. Although the therapeutic importance of these compounds has been evaluated, in many cases, an insufficient number of studies have examined their efficacy and safety. The effects demonstrated by various compounds, including 
strictosamide (antidepressant, analgesic, and anti-inflammatory), mitragynine (analgesic and antidepressant), harmane (antidepressant, spasmolytic, and antiplatelet), brucine (analgesic and anticancer), ellipticine (antimalarial and lipid-lowering), globospiramine (antimycobacterial), vindogentianine (antidiabetic), tabersonine (anticancer), scholarisine I (antifungal and anti-inflammatory), angustine (anticholinesterase and hypotensive), suggest that further in-depth studies should be performed to endorse the clinical effectiveness of these compounds. In addition, the mechanistic activities at the sites of action and toxicity studies should be thoroughly investigated to identify suitable lead compounds for further development. Due to the lack of extensive pharmacological information regarding these compounds obtained from previous studies, new clinical studies that are performed using well-developed methodologies remain necessary to identify new therapeutic agents with increased efficacy and reduced side effects. The pk properties of some compounds have also shown promising results that should be explored further. This review can be useful for researchers who plan to extensively study indole alkaloids in the future.

Author Contributions: Conceptualization, methodology, and writing —original draft preparation, F.O.; investigation and writing-review and editing, A.M.T., A.M.A., K.D., T.B.E., and J.S.-G.; visualization, supervision, and project administration, M.A.S. and J.S.-G.; funding acquisition, J.S.-G. All authors have read and agreed to the published version of the manuscript.

Funding: This research received no external funding.

Institutional Review Board Statement: Not applicable.

Informed Consent Statement: Not applicable.

Data Availability Statement: Available data are presented in the manuscript.

Conflicts of Interest: The authors declare no conflict of interest.

\section{References}

1. Baeyer, A. Ueber die Reduction aromatischer Verbindungen mittelst Zinkstaub. Justus Liebigs Ann. Der Chem. 1866, 140, 295-296. [CrossRef]

2. Kaushik, N.K.; Kaushik, N.; Attri, P.; Kumar, N.; Kim, C.H.; Verma, A.K.; Choi, E.H. Biomedical importance of indoles. Molecules 2013, 18, 6620-6662. [CrossRef]

3. Otero, N.; Mandado, M.; Mosquera, R.A. Nucleophilicity of Indole Derivatives: Activating and Deactivating Effects Based on Proton Affinities and Electron Density Properties. J. Phys. Chem. A 2007, 111, 5557-5562. [CrossRef]

4. Dewick, P.M. Essentials of Organic Chemistry: For Students of Pharmacy, Medicinal Chemistry and Biological Chemistry; John Wiley \& Sons: Hoboken, NJ, USA, 2006.

5. Wang, W.; Cheng, M.-H.; Wang, X.-H. Monoterpenoid indole alkaloids from Alstonia rupestris with cytotoxic, anti-inflammatory and antifungal activities. Molecules 2013, 18, 7309-7322. [CrossRef]

6. Xu, S.Y.; Bian, R.L.; Chen, X. Methods of Pharmacology Experiment; People's Sanitation Press: Beijing, China, 2003 ; pp. $1651-1653$.

7. Yu, H.-F.; Qin, X.-J.; Ding, C.-F.; Wei, X.; Yang, J.; Luo, J.-R.; Liu, L.; Khan, A.; Zhang, L.-C.; Xia, C.-F. Nepenthe-like indole alkaloids with antimicrobial activity from Ervatamia chinensis. Org. Lett. 2018, 20, 4116-4120. [CrossRef]

8. Cheng, G.-G.; Li, D.; Hou, B.; Li, X.-N.; Liu, L.; Chen, Y.-Y.; Lunga, P.-K.; Khan, A.; Liu, Y.-P.; Zuo, Z.-L.; et al. Melokhanines A-J, Bioactive Monoterpenoid Indole Alkaloids with Diverse Skeletons from Melodinus khasianus. J. Nat. Prod. 2016, 79, $2158-2166$. [CrossRef] [PubMed]

9. Zhang, L.; Zhang, C.-J.; Zhang, D.-B.; Wen, J.; Zhao, X.-W.; Li, Y.; Gao, K. An unusual indole alkaloid with anti-adenovirus and anti-HSV activities from Alstonia scholaris. Tetrahedron Lett. 2014, 55, 1815-1817. [CrossRef]

10. Tan, C.-J.; Di, Y.-T.; Wang, Y.-H.; Zhang, Y.; Si, Y.-K.; Zhang, Q.; Gao, S.; Hu, X.-J.; Fang, X.; Li, S.-F. Three new indole alkaloids from Trigonostemon lii. Org. Lett. 2010, 12, 2370-2373. [CrossRef] [PubMed]

11. Liu, Y.-P.; Liu, Q.-L.; Zhang, X.-L.; Niu, H.-Y.; Guan, C.-Y.; Sun, F.-K.; Xu, W.; Fu, Y.-H. Bioactive monoterpene indole alkaloids from Nauclea officinalis. Bioorganic Chem. 2019, 83, 1-5. [CrossRef]

12. Rahman, J.; Tareq, A.M.; Hossain, M.M.; Sakib, S.A.; Islam, M.N.; Uddin, A.B.M.N.; Hoque, M.; Nasrin, M.S.; Ali, M.H.; Caiazzo E.; et al. Biological evaluation, DFT calculations and molecular docking studies on the antidepressant and cytotoxicity activities of Cycas pectinata Buch.-Ham. Compounds. Pharmaceuticals 2020, 13, 232. [CrossRef]

13. Bristy, T.A.; Barua, N.; Tareq, A.M.; Sakib, S.A.; Etu, S.T.; Chowdhury, K.H.; Jyoti, M.A.; Aziz, M.; Ibn, A.; Reza, A. Deciphering the pharmacological properties of methanol extract of Psychotria calocarpa leaves by in vivo, in vitro and in silico approaches. Pharmaceuticals 2020, 13, 183. [CrossRef] [PubMed] 
14. Farzin, D.; Mansouri, N. Antidepressant-like effect of harmane and other B-carbolines in the mouse forced swim test. Int. J. Neuropsychopharmacol. 2008, 11, 126. [CrossRef]

15. Both, F.L.; Meneghini, L.; Kerber, V.A.; Henriques, A.T.; Elisabetsky, E. Psychopharmacological profile of the alkaloid psychollatine as a 5HT2A/C serotonin modulator. J. Nat. Prod. 2005, 68, 374-380. [CrossRef]

16. Xiang-Hai, C.A.I.; Jiang, H.; Yan, L.I.; Cheng, G.-G.; Ya-Ping, L.I.U.; Tao, F.; Xiao-Dong, L.U.O. Cytotoxic indole alkaloids from Melodinus fusiformis and M. morsei. Chin. J. Nat. Med. 2011, 9, 259-263.

17. Deng, X.-K.; Yin, W.; Li, W.-D.; Yin, F.-Z.; Lu, X.-Y.; Zhang, X.-C.; Hua, Z.-C.; Cai, B.-C. The anti-tumor effects of alkaloids from the seeds of Strychnos nux-vomica on HepG2 cells and its possible mechanism. J. Ethnopharmacol. 2006, 106, 179-186. [CrossRef] [PubMed]

18. Sichaem, J.; Surapinit, S.; Siripong, P.; Khumkratok, S.; Jong-aramruang, J.; Tip-pyang, S. Two new cytotoxic isomeric indole alkaloids from the roots of Nauclea orientalis. Fitoterapia 2010, 81, 830-833. [CrossRef]

19. Mishra, D.P.; Khan, M.A.; Yadav, D.K.; Rawat, A.K.; Singh, R.K.; Ahamad, T.; Hussain, M.K.; Saquib, M.; Khan, M.F. Monoterpene indole alkaloids from Anthocephalus cadamba fruits exhibiting anticancer activity in human lung cancer cell line H1299. ChemistrySelect 2018, 3, 8468-8472. [CrossRef]

20. Guo, L.-L.; He, H.-P.; Di, Y.-T.; Li, S.-F.; Cheng, Y.-Y.; Yang, W.; Li, Y.; Yu, J.-P.; Zhang, Y.; Hao, X.-J. Indole alkaloids from Ervatamia chinensis. Phytochemistry 2012, 74, 140-145. [CrossRef] [PubMed]

21. Raja, V.J.; Lim, K.-H.; Leong, C.-O.; Kam, T.-S.; Bradshaw, T.D. Novel antitumour indole alkaloid, Jerantinine A, evokes potent G2/M cell cycle arrest targeting microtubules. Investig. New Drugs 2014, 32, 838-850. [CrossRef] [PubMed]

22. Fang, L.; Tian, S.-M.; Zhou, J.; Lin, Y.-L.; Wang, Z.-W.; Wang, X. Melaxillines A and B, monoterpenoid indole alkaloids from Melodinus axillaris. Fitoterapia 2016, 115, 173-176. [CrossRef]

23. Cao, P.; Liang, Y.; Gao, X.; Li, X.-M.; Song, Z.-Q.; Liang, G. Monoterpenoid indole alkaloids from Alstonia yunnanensis and their cytotoxic and anti-inflammatory activities. Molecules 2012, 17, 13631-13641. [CrossRef]

24. Jahan, I.; Tona, M.R.; Sharmin, S.; Sayeed, M.A.; Tania, F.Z.; Paul, A.; Chy, M.; Uddin, N.; Rakib, A.; Emran, T.B. GC-MS phytochemical profiling, pharmacological properties, and in silico studies of Chukrasia velutina leaves: A novel source for bioactive agents. Molecules 2020, 25, 3536. [CrossRef] [PubMed]

25. Yin, W.; Wang, T.-S.; Yin, F.-Z.; Cai, B.-C. Analgesic and anti-inflammatory properties of brucine and brucine N-oxide extracted from seeds of Strychnos nux-vomica. J. Ethnopharmacol. 2003, 88, 205-214. [CrossRef]

26. Shamima, A.R.; Fakurazi, S.; Hidayat, M.T.; Hairuszah, I.; Moklas, M.A.M.; Arulselvan, P. Antinociceptive action of isolated mitragynine from Mitragyna speciosa through activation of opioid receptor system. Int. J. Mol. Sci. 2012, 13, 11427-11442. [CrossRef] [PubMed]

27. Rakib, A.; Ahmed, S.; Islam, M.A.; Uddin, M.M.N.; Paul, A.; Chy, M.N.U.; Emran, T.B.; Seidel, V. Pharmacological studies on the antinociceptive, anxiolytic and antidepressant activity of Tinospora crispa. Phytother. Res. 2020, 34, 2978-2984. [CrossRef] [PubMed]

28. Rakib, A.; Ahmed, S.; Islam, M.A.; Haye, A.; Uddin, S.N.; Uddin, M.M.N.; Hossain, M.K.; Paul, A.; Emran, T.B. Antipyretic and hepatoprotective potential of Tinospora crispa and investigation of possible lead compounds through in silico approaches. Food Sci. Nutr. 2020, 8, 547-556. [CrossRef]

29. Tiong, S.H.; Looi, C.Y.; Hazni, H.; Arya, A.; Paydar, M.; Wong, W.F.; Cheah, S.-C.; Mustafa, M.R.; Awang, K. Antidiabetic and antioxidant properties of alkaloids from Catharanthus roseus (L.) G. Don. Molecules 2013, 18, 9770-9784. [CrossRef]

30. Tiong, S.H.; Looi, C.Y.; Arya, A.; Wong, W.F.; Hazni, H.; Mustafa, M.R.; Awang, K. Vindogentianine, a hypoglycemic alkaloid from Catharanthus roseus (L.) G. Don (Apocynaceae). Fitoterapia 2015, 102, 182-188. [CrossRef]

31. Shittu, H.; Gray, A.; Furman, B.; Young, L. Glucose uptake stimulatory effect of akuammicine from Picralima nitida (Apocynaceae). Phytochem. Lett. 2010, 3, 53-55. [CrossRef]

32. e Silva, L.F.R.; Montoia, A.; Amorim, R.C.N.; Melo, M.R.; Henrique, M.C.; Nunomura, S.M.; Costa, M.R.F.; Neto, V.F.A.; Costa, D.S.; Dantas, G. Comparative in vitro and in vivo antimalarial activity of the indole alkaloids ellipticine, olivacine, cryptolepine and a synthetic cryptolepine analog. Phytomedicine 2012, 20, 71-76. [CrossRef]

33. Fernandez, L.S.; Buchanan, M.S.; Carroll, A.R.; Feng, Y.J.; Quinn, R.J.; Avery, V.M. Flinderoles a-c: Antimalarial bis-indole alkaloids from flindersia species. Org. Lett. 2009, 11, 329-332. [CrossRef]

34. Mitaine-Offer, A.C.; Sauvain, M.; Valentin, A.; Callapa, J.; Mallié, M.; Zèches-Hanrot, M. Antiplasmodial activity of Aspidosperma indole alkaloids. Phytomedicine 2002, 9, 142-145. [CrossRef]

35. Mbeunkui, F.; Grace, M.H.; Lategan, C.; Smith, P.J.; Raskin, I.; Lila, M.A. In vitro antiplasmodial activity of indole alkaloids from the stem bark of Geissospermum vellosii. J. Ethnopharmacol. 2012, 139, 471-477. [CrossRef]

36. Liew, S.Y.; Mukhtar, M.R.; Hadi, A.H.A.; Awang, K.; Mustafa, M.R.; Zaima, K.; Morita, H.; Litaudon, M. Naucline, a new indole alkaloid from the bark of Nauclea officinalis. Molecules 2012, 17, 4028-4036. [CrossRef]

37. Koyama, K.; Hirasawa, Y.; Zaima, K.; Hoe, T.C.; Chan, K.-L.; Morita, H. Alstilobanines A-E, new indole alkaloids from Alstonia angustiloba. Bioorganic Med. Chem. 2008, 16, 6483-6488. [CrossRef]

38. Hirasawa, Y.; Dai, X.; Deguchi, J.; Hatano, S.; Sasaki, T.; Ohtsuka, R.; Nugroho, A.E.; Kaneda, T.; Morita, H. New vasorelaxant indole alkaloids, taberniacins A and B, from Tabernaemontana divaricata. J. Nat. Med. 2019, 73, 627-632. [CrossRef]

39. Matsuo, H.; Okamoto, R.; Zaima, K.; Hirasawa, Y.; Ismail, I.S.; Lajis, N.H.; Morita, H. New vasorelaxant indole alkaloids, villocarines A-D from Uncaria villosa. Bioorganic Med. Chem. 2011, 19, 4075-4079. [CrossRef]

40. Fadaeinasab, M.; Basiri, A.; Kia, Y.; Karimian, H.; Ali, H.M.; Murugaiyah, V. New indole alkaloids from the bark of Rauvolfia reflexa and their cholinesterase inhibitory activity. Cell. Physiol. Biochem. 2015, 37, 1997-2011. [CrossRef] 
41. Andrade, M.T.; Lima, J.A.; Pinto, A.C.; Rezende, C.M.; Carvalho, M.P.; Epifanio, R.A. Indole alkaloids from Tabernaemontana australis (Müell. Arg) Miers that inhibit acetylcholinesterase enzyme. Bioorganic Med. Chem. 2005, 13, 4092-4095. [CrossRef]

42. Zhan, Z.-J.; Yu, Q.; Wang, Z.-L.; Shan, W.-G. Indole alkaloids from Ervatamia hainanensis with potent acetylcholinesterase inhibition activities. Bioorganic Med. Chem. Lett. 2010, 20, 6185-6187. [CrossRef]

43. Liew, S.Y.; Khaw, K.Y.; Murugaiyah, V.; Looi, C.Y.; Wong, Y.L.; Mustafa, M.R.; Litaudon, M.; Awang, K. Natural indole butyrylcholinesterase inhibitors from Nauclea officinalis. Phytomedicine 2015, 22, 45-48. [CrossRef]

44. Im, J.-H.; Jin, Y.-R.; Lee, J.-J.; Yu, J.-Y.; Han, X.-H.; Im, S.-H.; Hong, J.T.; Yoo, H.-S.; Pyo, M.-Y.; Yun, Y.-P. Antiplatelet activity of $\beta$-carboline alkaloids from Perganum harmala: A possible mechanism through inhibiting PLC $\gamma 2$ phosphorylation. Vasc. Pharmacol. 2009, 50, 147-152. [CrossRef]

45. Mandal, S.; Nayak, A.; Kar, M.; Banerjee, S.K.; Das, A.; Upadhyay, S.N.; Singh, R.K.; Banerji, A.; Banerji, J. Antidiarrhoeal activity of carbazole alkaloids from Murraya koenigii Spreng (Rutaceae) seeds. Fitoterapia 2010, 81, 72-74. [CrossRef]

46. Jyoti, M.A.; Barua, N.; Hossain, M.S.; Hoque, M.; Bristy, T.A.; Mahmud, S.; Adnan, M.; Chy, M.; Uddin, N.; Paul, A.; et al. Unravelling the biological activities of the Byttneria pilosa leaves using experimental and computational approaches. Molecules 2020, 25, 4737. [CrossRef]

47. Diniz, M.F.M.; Da Silva, B.A.; Mukherjee, R. Spasmolytic actions of the new indole alkaloid trinervine from Strychnos trinervis root. Phytomedicine 1994, 1, 205-207. [CrossRef]

48. Da Silva, B.A.; de Araujo Filho, A.P.; Mukherjee, R.; Chiappeta, A.D.A. Bisnordihydrotoxiferine and vellosimine from Strychnos divaricans root: Spasmolytic properties of bisnordihydrotoxiferine. Phytother. Res. 1993, 7, 419-424. [CrossRef]

49. Al Mahmud, Z.; Qais, N.; Bachar, S.C.; Hasan, C.M.; Emran, T.B.; Uddin, M.M.N. Phytochemical investigations and antioxidant potential of leaf of Leea macrophylla (Roxb.). BMC Res. Notes 2017, 10, 245. [CrossRef]

50. Shi, C.C.; Liao, J.F.; Chen, C.F. Spasmolytic Effects of Three Harmala Alkaloids on Guinea-Pig Isolated Trachea. Pharmacol. Toxicol. 2001, 89, 259-264. [CrossRef]

51. Tanaka, J.C.A.; Da Silva, C.C.; Ferreira, I.C.P.; Machado, G.M.C.; Leon, L.L.; De Oliveira, A.J.B. Antileishmanial activity of indole alkaloids from Aspidosperma ramiflorum. Phytomedicine 2007, 14, 377-380. [CrossRef]

52. Yao-Hao, X.U.; Wei, L.I.; Yong, R.A.O.; Huang, Z.-S.; Sheng, Y.I.N. Pyridocarbazole alkaloids from Ochrosia borbonica: Lipidlowering agents inhibit the cell proliferation and adipogenesis of 3T3-L1 adipocyte via intercalating into supercoiled DNA. Chin. J. Nat. Med. 2019, 17, 663-671.

53. Tanaka, N.; Takao, M.; Matsumoto, T. Vincamine production in multiple shoot culture derived from hairy roots of Vinca minor. Plant Cell Tissue Organ Cult. 1995, 41, 61-64. [CrossRef]

54. Nandini, H.S.; Naik, P.R. Antidiabetic, antihyperlipidemic and antioxidant effect of Vincamine, in streptozotocin-induced diabetic rats. Eur. J. Pharmacol. 2019, 843, 233-239. [CrossRef] [PubMed]

55. Garcellano, R.C.; Cort, J.R.; Moinuddin, S.G.A.; Franzblau, S.G.; Ma, R.; Aguinaldo, A.M. An iboga alkaloid chemotaxonomic marker from endemic Tabernaemontana ternifolia with antitubercular activity. Nat. Prod. Res. 2020, 34, 1175-1179. [CrossRef] [PubMed]

56. Macabeo, A.P.G.; Vidar, W.S.; Chen, X.; Decker, M.; Heilmann, J.; Wan, B.; Franzblau, S.G.; Galvez, E.V.; Aguinaldo, M.A.M.; Cordell, G.A. Mycobacterium tuberculosis and cholinesterase inhibitors from Voacanga globosa. Eur. J. Med. Chem. 2011, 46, 3118-3123. [CrossRef] [PubMed]

57. Rahman, M.A.; bin Imran, T.; Islam, S. Antioxidative, antimicrobial and cytotoxic effects of the phenolics of Leea indica leaf extract. Saudi J. Biol. Sci. 2013, 20, 213-225. [CrossRef] [PubMed]

58. Guzmán-Gutiérrez, S.L.; Silva-Miranda, M.; Krengel, F.; Huerta-Salazar, E.; León-Santiago, M.; Díaz-Cantón, J.K.; Pinzón, C.E.; Reyes-Chilpa, R. Antimycobacterial Activity of Alkaloids and Extracts from Tabernaemontana alba and T. arborea. Planta Med. 2020. [CrossRef]

59. Saghir, S.A.; Ansari, R.A. Pharmacokinetics. In Reference Module in Biomedical Sciences; Elsevier: Amsterdam, The Netherlands, 2018.

60. Chen, J.; Xiao, H.-L.; Hu, R.-R.; Hu, W.; Chen, Z.-P.; Cai, H.; Liu, X.; Lu, T.-L.; Fang, Y.; Cai, B.-C. Pharmacokinetics of brucine after intravenous and oral administration to rats. Fitoterapia 2011, 82, 1302-1308. [CrossRef]

61. Janchawee, B.; Keawpradub, N.; Chittrakarn, S.; Prasettho, S.; Wararatananurak, P.; Sawangjareon, K. A high-performance liquid chromatographic method for determination of mitragynine in serum and its application to a pharmacokinetic study in rats. Biomed. Chromatogr. 2007, 21, 176-183. [CrossRef]

62. Manda, V.K.; Avula, B.; Ali, Z.; Khan, I.A.; Walker, L.A.; Khan, S.I. Evaluation of in vitro absorption, distribution, metabolism, and excretion (ADME) properties of mitragynine, 7-hydroxymitragynine, and mitraphylline. Planta Med. 2014, 80, 568-576. [CrossRef]

63. Lin, C.; Cai, J.; Yang, X.; Hu, L.; Lin, G. Liquid chromatography mass spectrometry simultaneous determination of vindoline and catharanthine in rat plasma and its application to a pharmacokinetic study. Biomed. Chromatogr. 2015, 29, 97-102. [CrossRef]

64. Li, S.; Teng, L.; Liu, W.; Cheng, X.; Jiang, B.; Wang, Z.; Wang, C.-h. Pharmacokinetic study of harmane and its 10 metabolites in rat after intravenous and oral administration by UPLC-ESI-MS/MS. Pharm. Biol. 2016, 54, 1768-1781. [CrossRef] [PubMed] 